Article

\title{
Examining Safety of Biocolourants from Fungal and Plant Sources-Examples from Cortinarius and Tapinella, Salix and Tanacetum spp. and Dyed Woollen Fabrics
}

\author{
Riikka Räisänen ${ }^{1, *}$, Anja Primetta ${ }^{1,2}$, Sari Nikunen ${ }^{1}$, Ulla Honkalampi ${ }^{3}$, Heli Nygren ${ }^{4}$, \\ Juha-Matti Pihlava ${ }^{5}$, Ina Vanden Berghe ${ }^{6}{ }^{-}$and Atte von Wright ${ }^{3}$ \\ 1 Craft Studies, University of Helsinki, P.O. Box 8, 00014 Helsinki, Finland; anja.primetta@helsinki.fi (A.P.); \\ sari.nikunen@gmail.com (S.N.) \\ 2 Department of Environmental and Biological Sciences, University of Eastern Finland, P.O. Box 1627, \\ 70211 Kuopio, Finland \\ 3 Department of Pharmacology and Toxicology, University of Eastern Finland, P.O. Box 1627, \\ 70211 Kuopio, Finland; u.honkalampi@innolact.fi (U.H.); atte.vonwright@uef.fi (A.v.W.) \\ 4 VTT Technical Research Centre of Finland Ltd., P.O. Box 1000, 02044 Espoo, Finland; heli.nygren@vtt.fi \\ 5 Natural Resources Institute Finland (Luke), Tietotie 4, 31600 Jokioinen, Finland; juha-matti.pihlava@luke.fi \\ 6 Royal Institute for Cultural Heritage (IRPA/KIK), Parc du Cinquantenaire 1, 1000 Brussels, Belgium; \\ ina.vandenberghe@kikirpa.be \\ * Correspondence: riikka.raisanen@helsinki.fi; Tel.: +358-503183973
}

Received: 31 March 2020; Accepted: 18 May 2020; Published: 20 May 2020

\begin{abstract}
Biocolourants have been investigated as alternatives to synthetic dyes. However, natural origin per se is not a label of harmlessness and research is needed to obtain safe dyes. We studied the cytotoxicity of the extracts from fungal (Cortinarius semisanguineus, Tapinella atrotomentosa) and plant (Tanacetum vulgare, Salix phylicifolia) sources and the woollen fabrics dyed with the extracts. Cytotoxicity in vitro using hepa-1 mouse hepatoma cells for $24 \mathrm{~h}$ and $72 \mathrm{~h}$ exposure was observed as the highest tolerated dose. All biocolourants produced intensive colour on fabrics with fastness properties from moderate to good. The Salix and Cortinarius samples did not show any cytotoxic effects, whereas the Tanacetum and Tapinella samples had slightly higher test values but were not interpreted as being significantly toxic. Higher than zero values of the undyed fabrics showed the importance of examining their toxicity as well. It was found that the cytotoxicity of the samples dyed with the biocolourants did not differ significantly from the undyed wool fabric. The concentrations of dyes used in the assays were very low, imitating the dose of the user. In addition to colouring properties, natural dyes may have pharmaceutical and antibacterial properties which would enhance the interest in using them in products for added value.
\end{abstract}

Keywords: natural dye; biocolourant; secondary metabolite; in vitro; cytotoxicity; mouse hepatoma cell; highest tolerated dose; HPLC-UV/Vis-MS

\section{Introduction}

\subsection{Background}

The environmental disadvantages of synthetic dyes are well known. The textile industry discharges large amounts of highly coloured effluent wastewater, the dyes of which severely affect photosynthesis and aquatic life. Effluents may also contain toxic amounts of metal ions and chlorine [1]. In textile workers and end-users, synthetic colourants may cause adverse reactions, such as allergies, urticaria 
and dermatitis, or respiratory difficulties like asthma, in addition to cytotoxic, genotoxic, carcinogenic and mutagenic effects [2-5].

Alternative colourants among secondary metabolites from plant and microbial sources such as fungi, yeast and algae have been explored. The natural origin does not automatically mean non-toxicity. Also, the different stages of the textile production process have an impact on the final product, its safety to the consumer, and the environmental load. The degradability of biocolourants is a positive feature in circular material production, whereas in the textile dyeing process, the requirements of colourants are set in high affinity to fibres and stability under end-use conditions. Thus, the utilisation of bio-based colourants requires careful consideration of dye technical and toxicological properties as well as economic feasibility, in which the multi-functionality through antimicrobial and UV-protective properties can create interesting prospects.

Our aim in this article is to examine the information about the safety of natural colourants and the results from the preliminary tests of a few dyes of fungal and plant origins. In this study, fungi surprise webcap [Cortinarius semisanguineus (Fr.) Gillet] and velvet roll-rim [Tapinella atrotomentosa (Batsch.) Šutara] and plants tansy (Tanacetum vulgare L.) and willow bark (Salix phylicifolia L.) were used as sources of biocolourants for dyeing of woollen fabrics.

\subsection{Safety and Medicinal Use Related to Fungal and Plant Colourants}

Correct identification and characterisation of the biocolourant's source is crucial when assessing potential toxicity, as toxic compounds are concentrated in certain taxa [6,7]. Different taxa, whether fungi or plants, also have their own typical colourants [8-11]. For Rubia and Cortinarius genera, the anthraquinones provide a variety of red hues, whereas yellow-orange flavonoids and carotenoids can be obtained from Tanacetum species, and bluish-violet terphenyl quinones from Tapinella fungi [12,13].

Plant parts such as stems, leaves, flowers, roots, bark, berries, and cones vary in the composition and contents of biocolourants according to the developmental stage and harvesting time $[6,10,14-17]$. The contents may also vary depending on the geographical area, cultivation practices and storage conditions [18-22].

The pre-handling steps such as drying and grinding and subsequent extraction conditions (e.g., solvent) affect the content of biocolourants [13,23-25]. However, after drying at $45^{\circ} \mathrm{C}$ for 1 week, milling to a powder and storage for more than a year, at least two native enzymes in madder roots (Rubia tinctorum L.) were still highly active upon addition of water, and depending on the conditions, caused conversion of molecules into forms, some of which were toxic [26].

Natural dyes are complex mixtures of dye components, setting challenges for industrial utilisation. Repeatable colour can be achieved by using standardised extraction and quality analyses of the dye components in the mixtures or by producing single component purified dyes $[13,25]$. The improved repeatability of colour components will also minimise variation of other secondary metabolites and risks of toxic properties.

By understanding reaction mechanisms and how the reactions can be controlled [26], the safety risks can be minimised. Those reactions may also affect the dyeing potential, as the products of hydrolysis, i.e., aglycone structures, differ in their properties and affinities to various materials compared to their derivatives $[9,13]$. The historical background does not necessarily give any guarantee of safeness as even widely-used dye sources can contain toxic secondary metabolites: madder root extracts ( $R$. tinctorum) having alizarin (1) as the main anthraquinone aglycone, also contained toxic lucidin (2), rubiadin (3) and xanthopurpurin (4) (Table 1) [26-30], of which lucidin and xanthopurpurin were hydrolysis and decarboxylation products of lucidin primeveroside and munjistin. Furthermore, it has been proposed that lucidin is converted into other compounds, such as nordamnacanthal or quinone methide $[26,28,31]$ or degrade to xanthopurpurin. 
Table 1. Chemical structures of some natural anthraquinones.

\begin{tabular}{|c|c|}
\hline Chemical Compound & Structure \\
\hline $\begin{array}{c}\text { Alizarin (1) } \\
\mathrm{C}_{14} \mathrm{H}_{8} \mathrm{O}_{4} \\
\mathrm{M}=240.21 \mathrm{~g} \mathrm{~mol}^{-1}\end{array}$ & \\
\hline $\begin{array}{c}\text { Lucidin (2) } \\
\mathrm{C}_{15} \mathrm{H}_{10} \mathrm{O}_{5} \\
\mathrm{M}=270.24 \mathrm{~g} \mathrm{~mol}^{-1}\end{array}$ & \\
\hline 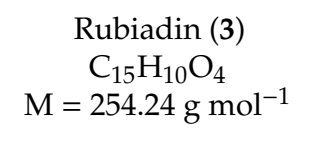 & \\
\hline $\begin{array}{c}\text { Xanthopurpurin/ } \\
\text { Purpuroxanthine (4) } \\
\mathrm{C}_{14} \mathrm{H}_{8} \mathrm{O}_{4} \\
\mathrm{M}=240.21 \mathrm{~g} \mathrm{~mol}^{-1}\end{array}$ & \\
\hline
\end{tabular}

Toxicity studies of colour providing secondary metabolites, e.g., those of anthraquinones, have given somewhat contradictory results. Jäger et al. [27] detected lucidin (2), rubiadin (3) and xanthopurpurin (4) being mutagenic, but not alizarin (1) (Table 1), in madder root extracts (EtOAc). However, all the madder dyed wool samples had mutagenic effects in Ames assays (strain TA100). Previously, Yasui and Takeda [29] had found that the madder root extracts (EtOAc) were mutagenic for both strains of S. typhimurium (TA100 and TA98). They concluded that all mutagenic activity found in the EtOAc extracts was due to lucidin. However, Kawasaki et al. [32] suggested that the mutagenicity of the extracts of $R$. tinctorum was not exclusively due to lucidin but also a result and contribution of other mutagenic compounds.

The chemical structures of secondary metabolites and their functional groups, for example, hydroxyl, alkyl, alkoxy or chlorine, attached at specific positions, can confer different biological activities and genotoxicity profiles [33-35]. Lucidin (2) and rubiadin (3), which are 1,3-dihydroxyanthraquinones possessing a methyl or hydroxymethyl group at carbon 2, showed strong mutagenicity, whereas alizarin (1), 1,2-dihydroxyanthraquinone without other substituents, had no mutagenicity. Further, 4,5-dihydroxylation of 2-methyl anthraquinones did not have any apparent effect on the mutagenicity. The results suggested that both the number of $\mathrm{OH}$-groups and their positions are relevant for the mutagenicity [32].

Many studies have found antimicrobial properties in biocolourants [36-38]. When testing toxicity in vitro, it is important to analyse the conditions and observed changes in detail to distinguish between toxic and non-toxic antimicrobial activity. Antimicrobial activity can be considered toxic (i.e., cytotoxic) if it induces changes at the level of cell structure [39].

\subsection{Flavonoids and Carotenoids in Tanacetum Vulgare}

T. vulgare L., commonly called tansy (Table 2), is a flowering herbaceous plant widely distributed in the Northern Hemisphere and known for its curing properties for colds and fevers [39].

Tansy has been reported for its variety of chemotypes based on the most predominant constituent in the essential oil, which may change according to its growth stage [16]. In addition to typical monoterpenes, less volatile sesquiterpenes, sesquiterpene lactones, non-volatile terpenes, flavonoids, and phenolic acids are also present [15,40-45]. Flavonoids and carotenoids are the major colouring 
constituents in T. vulgare. For dyeing purposes, the whole plant can be used, resulting in a greenish-yellow colour, while flower heads produce bright yellow $[13,46]$.

In the flower heads, luteolin (5), quercetin (6), violaxanthin (7), $\beta$-carotene (8) (Table 2) and their derivatives are dominating colourant components [12,13], whereas caffeic, ferulic and neochlorogenic acid and their derivatives occur in all plant parts [12,37,47-49]. The amounts of potentially harmful alkaloids and terpenes (e.g., sesquiterpene lactones) depend largely on the chemotype. Exo-methylene group in the lactone is regarded to be essential for the cytotoxicity, but also the presence of the $\mathrm{O}=\mathrm{C}-\mathrm{C}=\mathrm{CH}_{2}$ system has been shown to be responsible $[40,42,50]$.

Devrnja et al. [37] identified neochlorogenic acid, 3,5-O-dicaffeoylquinic acid, dicaffeoylquinic acid and quercetin-3-O-glucoside as the main secondary metabolites from the $\mathrm{MeOH}$ extracts of tansy flower heads. The extracts exhibited a strong antiproliferative effect on human cervical adenocarcinoma (HeLa) cells causing cell shrinkage and detachment but did not lead to a significant cell detachment of human non-tumour cells (MRC-5) under the same conditions. The tansy was categorised as trans-chrysanthenyl acetate chemotype with low proportions $(<10 \%)$ of generally harmful monoterpenes trans- and cis-thujone [37]. The water extract of tansy leaves possessed a strong diuretic action but no renal toxicity or other detrimental effects in tests on rats [51-54].

\subsection{Tannins in Salix spp.}

Salix species (Table 2) are deciduous shrubs, trees or subshrubs occurring mainly in the temperate and arctic areas of the Northern Hemisphere. Leaves and bark are rich in secondary metabolites such as condensed tannins, constituting approx. $2-3 \%$ of dry weight $(\mathrm{dw})[10,23,55,56]$ but even $10 \%(\mathrm{dw})$ in twigs (Salix pyrolifolia Ledeb.) [10]. Tannins bind to proteins and carbohydrates and accumulate alkaloids and metals (e.g., Al, Fe, Cu). Traditionally, willows (Salix spp.) have been considered safe, as they have been used as a medicine to reduce fever, inflammation and pain. Adverse effects of bark extracts appear to be minimal. The primary risk may relate to allergic reactions in salicylate-sensitive individuals [57,58].

The composition of secondary metabolites varies highly among Salix species, between genotypes and hybrids $[10,14,56,59,60]$. The condensed tannins in willow bark are procyanidins, which consist of chains with varying numbers of flavan-3-ol monomers linked to each other. The bark contains higher amounts of phenolics and higher diversity of glycosides than the leaves $[14,59,61,62]$. In dyeing, tannins produce browns and can be used as biomordants [13].

Salix bark contains simple phenolic glucosides like picein (9), triandrin (10), catechin (11) and salireposide (12) as main colourants reported by Dou et al. [63]. Salix spp. also contain other phenolics, such as phenolic acids, flavones and chalcones and yellow providing flavonols, especially quercetin (6) derivatives.

\subsection{Anthraquinones in Cortinarius Semisanguineus}

Cortinarius spp. are ectomycorrhizal fungi growing mainly in coniferous forests. Of the secondary metabolites, fungi Cortinarius, subgroup Dermocybe, are rich in monomeric anthraquinones also containing dimeric pre-anthraquinones of flavomannin type [13,64-68].

The fruiting bodies of $C$. semisanguineus (Table 2$)$ are relatively small $(<10 \mathrm{~cm}$, cap $\emptyset 3-9 \mathrm{~cm})$, but are produced in large numbers by the mycelia. Among the more abundant compounds are emodin (13), emodin-1-glucoside, dermocybin (14), dermocybin-1-glucoside and dermorubin (15). Also, physcion (16), dermolutein, 5-chlorodermolutein, 5-chlorodermorubin, dermoglaucin, endocrocin, and erythroglaucin have been found [68]. Anthraquinones from Cortinarius species have inhibited the growth of Staphylococcus aureus and P. auerugosa [69], and many anthraquinones have bioactive properties [70].

Macromycetes have mostly been studied for their oral toxicity in humans [71]. Highly nephrotoxic bipyridine orellanine, which is a good aluminium ion chelator, has been found in Cortinarius orellanus from Europe and Cortinarius armillatus native to North America [67,72,73]. Because Cortinarius fungi 
are endemic, it should not be assumed that toxins in European species are similarly present or absent in species of other regions, even if they appear morphologically similar [72,73]. Orellanine has not been found in the European species of C. armillatus, nor in Cortinarius sanguineus (syn. Dermocybe sanguinea) [74] or C. semisanguineus [75], which all contain anthraquinones and have been used for dyeing [13].

Toxicity tests for anthraquinones [33,37] show that the structural requirements for their mutagenicity in Salmonella typhimurium are not so clear. It has been suggested that the presence of alkyl or alkoxy groups in the anthraquinone structure, e.g., of chrysophanol, emodin (13), icelandicin, lucidin-2-ethyl ether, dermoglaucin, catenarin, and cynodontin, results in changes in cell tests [33].

Emodin (13) and dermoglaucin were found to be non-toxic for Bacillus subtilis in rec-assay and E. coli in pol A assay. However, dermocybin (14) showed very slight mutagenicity for B. subtilis, but no toxicity for E. coli [33]. There are an increasing number of reports regarding adverse effects of emodin (13). It has been reported to induce genotoxicity, reproductive toxicity, and also hepatotoxicity and nephrotoxicity, presumably connected to high doses and long-term use [76,77].

Von Wright et al. [78] studied the genotoxicity of the crude fractions from the extracts of C. sanguineus using an in vitro bacterial repair assay (E. coli; strains WP2 and CM871), a sister-chromatid exchange (SCE) test and a mouse hepatoma cell assay (Hepa-1c1c7). Emodin (13) was the most abundant (44\%) compound in Fraction I. Analysis showed that standard emodin was not toxic to either of the E. coli strains. However, it induced more SCEs than Fractions I and IV. Fraction I was clearly positive in both SCE- and Hepa-1 tests and in E. coli assays, indicating that other emodin-related but yet unidentified compounds were responsible for the observed cytotoxic and clastogenic effects. It was concluded that the different test results had somewhat contrary results and discrepancies existed between SCEs and E. coli assay tests results.

\subsection{Terphenyl Quinones in Tapinella Atrotomentosa}

T. atrotomentosa (syn. Paxillus atrotomentosus) (Table 2) is a sturdy dark brown-capped wood rotting fungus, with a dark brown, velvety stalk, and rim of the unsymmetrical cap. It is common on moss-covered pine stumps in boreal forests, pine moors and forest edges in Europe, North America and Asia $[13,38]$. The easily harvestable pale flesh fruiting body can grow to a relatively large size (cap $\emptyset \geq 20 \mathrm{~cm}$ ) and is rich in colourants. T. atrotomentosa has not proved to be toxic but no dietary use has been recommended [36,79].

The colourants isolated from its fresh fruiting bodies typically have a terphenyl quinone structure [80]. The $p$-terphenyl core (Table 2, 17) is essentially restricted to fungi and lichens and the structure was found to possess notable antiproliferative, antibacterial, antioxidant, and anti-inflammatory activities [38].

Atromentin (17) isolated from T. atrotomentosa is responsible for the brown colour. It occurs as colourless precursors, leucomentins 2 and $3(\mathbf{1 8}, \mathbf{1 9})$ in the flesh $[38,80]$, and its content may be ca. $2 \%$ of the fungal mass $(\mathrm{dw})$, those of leucomentins about 5\% [80]. Orange-yellow flavomentins and violet spiromentins (20) [81,82], osmundalactones and ergostane-type ecdysteroids (e.g., paxillosterone and atrotosterones A-C) have also been found [38,82].

T. atrotomentosa has a broad-spectrum of antimicrobial activity against $\mathrm{Gram}^{+}$and $\mathrm{Gram}^{-}$ pathogens, and a significant inhibitory activity against resistant bacterial strains, e.g., MRSA [38]. A recent investigation showed that violet colour providing spiromentins B and C (spiromentin core (20), Table 2) have strong antibacterial activity against multiresistant Acinetobacter baumannii and E. coli [38]. 
Table 2. Sources used in this research, their main colouring compounds as aglycones and dyeing results on wool as CIELab coordinates L, $\mathrm{a}^{*}, \mathrm{~b}^{*}$. (Photos: Riikka Räisänen, except Salix phylicifolia by Jouko Rikkinen [74]).

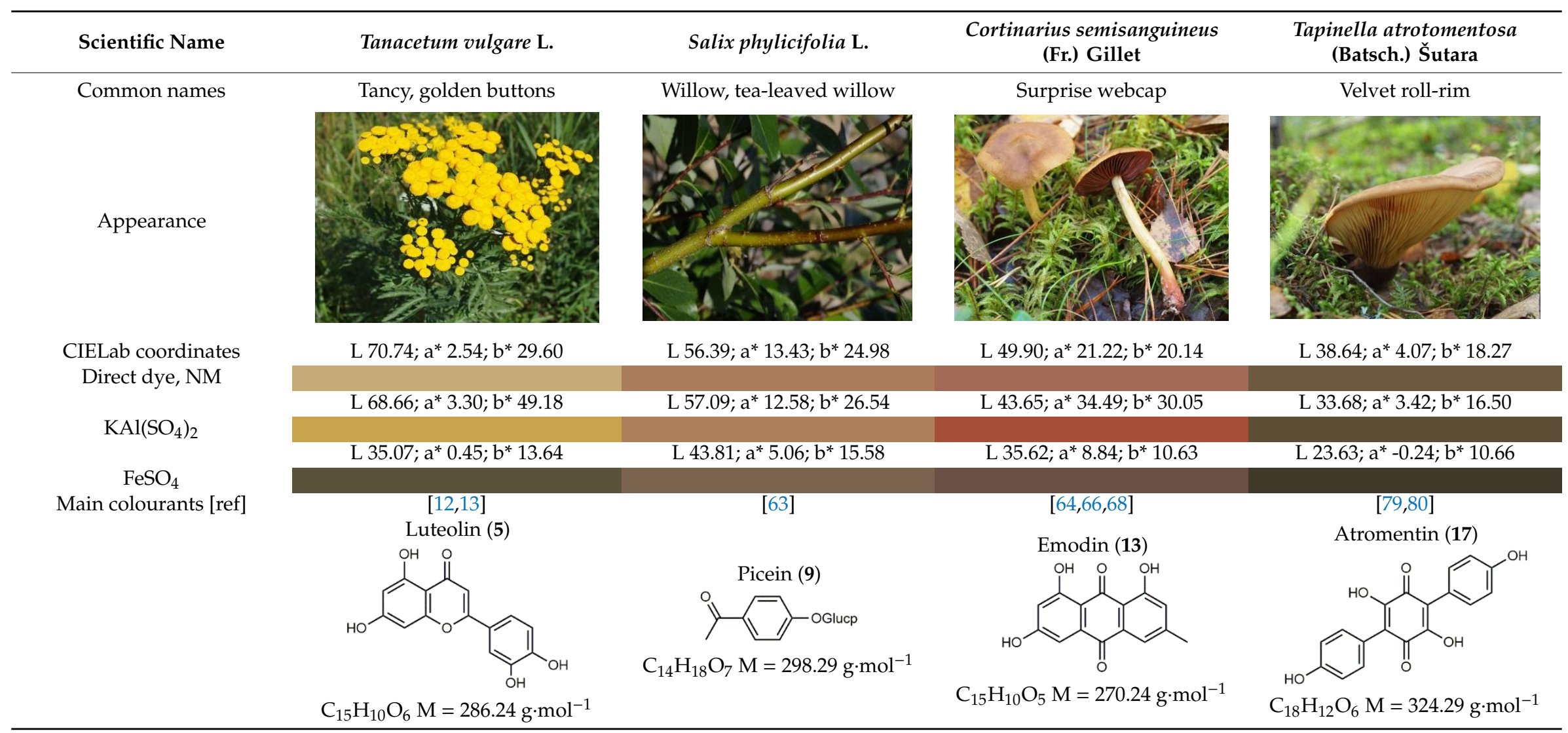


Table 2. Cont

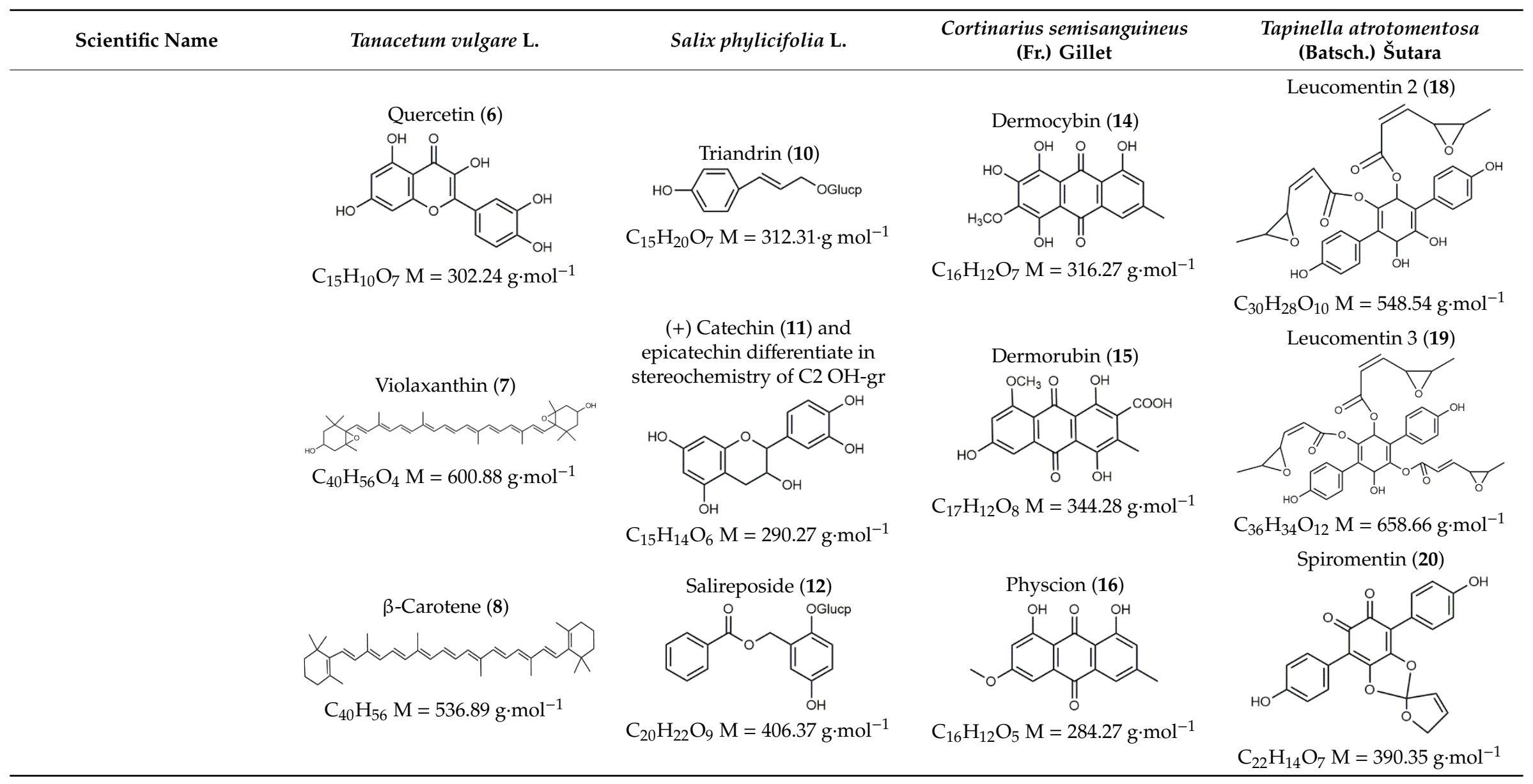




\subsection{Objectives}

Our aim with this paper was to discuss the toxicity of the examined biocolourants, their sources and the dyed textile samples. We evaluated the results of cytotoxicity tests when two plant species, T. vulgare and S. phylicifolia, and two fungal species, C. semisanguineus and T. atrotomentosa, were used as natural dye sources. The extracts were obtained directly from plant and fungal material and the wool fabrics dyed with them. Preliminary toxicity screening was performed using Hepa-1 mouse hepatoma cell tests in vitro and examining the highest tolerated dose (HTD) after exposures of 24 and $72 \mathrm{~h}$. The data obtained were analysed by statistical means.

Common natural dye sources T. vulgare, S. phylicifolia, C. semisanguineus, and T. atrotomentosa were chosen due to their high colouring and pharmacological potential, and the information we already had gained of their characteristics and dyeing properties [13,18,46,63,68,83,84]. The characteristic colourants of the studied plants and fungi are described in Table 2.

\section{Results}

\subsection{Colourants and Colourfastness}

The main colourants of the fungal and plant species under study were tentatively identified and the results can be seen in the HPLC-UV/Vis-MS spectra in Figure 1 and Table 3. Our analysis is in accordance with the previously published works as described in Introduction. The tentative identification of flavonoids (T. vulgare) from the MS data revealed the presence of several flavonol and flavone glycosides such as the derivatives of quercetin, apigenin and luteolin. Furthermore, caffeoylquinic acid isomers and dicaffeoylquinic acids were tentatively identified, which is in accordance with the literature [37].

Table 3. The results of the HPLC-UV/Vis-MS data of Tanacetum vulgare, Cortinarius semisanguineus and Tapinella atrotomentosa. The chemical structures and the calculated MS of the numbered compounds are found in Table 2. The MS data for C. semisanguineus refers to our earlier data published in [68] and [85].

\begin{tabular}{|c|c|c|c|c|}
\hline Ret. Time & $\begin{array}{c}\text { UV/Vis } \\
\lambda_{\max }[\mathrm{nm}]\end{array}$ & $\begin{array}{c}\text { MS Data: } m / z \\
{[\mathbf{M}-\mathbf{H}] /[\mathbf{M}+\mathbf{H}]^{+}} \\
\text {and Main Fragment }\end{array}$ & Molecular Formula & Compound \\
\hline \multicolumn{5}{|c|}{ Tanacetum vulgare, Figure 1, chromatogram (370 nm) and spectra A } \\
\hline 13.61 & $218,244,298 \mathrm{sh} \ddagger, 328$ & $353.0864 ; 191.0535$ & $\mathrm{C}_{16} \mathrm{H}_{18} \mathrm{O}_{9}$ & Caffeoylquinic acid isomer I \\
\hline 25.42 & $204,256,366$ & $463.0878 ; 301.0331$ & $\mathrm{C}_{21} \mathrm{H}_{20} \mathrm{O}_{12}$ & Quercetin (6) derivative \\
\hline 27.10 & $218,244,298$ sh, 328 & $515.1186 ; 353.0859$ & $\mathrm{C}_{25} \mathrm{H}_{24} \mathrm{O}_{12}$ & Caffeoylquinic acid isomer II \\
\hline 29.75 & $200,266,336$ & $445.0759 ; 269.0428$ & $\mathrm{C}_{21} \mathrm{H}_{18} \mathrm{O}_{11}$ & Apigenin derivative \\
\hline 30.13 & $218,244,300 \mathrm{sh}, 328$ & $515.1191 ; 353.0863$ & $\mathrm{C}_{25} \mathrm{H}_{24} \mathrm{O}_{12}$ & Caffeoylquinic acid isomer III \\
\hline 31.55 & $204,254,266,346$ & $639.3185 ; 285.0378$ & - & Luteolin (5) derivative \\
\hline 40.09 & $206,266,336$ & 269.0427 & $\mathrm{C}_{15} \mathrm{H}_{10} \mathrm{O}_{5}$ & Apigenin \\
\hline 41.13 & $204,254,266,346$ & 285.0388 & $\mathrm{C}_{15} \mathrm{H}_{10} \mathrm{O}_{6}$ & Luteolin (5) \\
\hline \multicolumn{5}{|c|}{ Cortinarius semisanguineus, Figure 1 , chromatogram $(440 \mathrm{~nm})$ and spectra B } \\
\hline 15.91 & $224,286,438$ & $327 ; 283$ & $\mathrm{C}_{17} \mathrm{H}_{12} \mathrm{O}_{7}$ & Dermolutein \\
\hline 16.64 & $250,285,434$ & - & $\mathrm{C}_{17} \mathrm{H}_{11} \mathrm{ClO}_{7}$ & 5-Cl-Demolutein \\
\hline 18.16 & $224,288,439$ & 684 & $\mathrm{C}_{21} \mathrm{H}_{20} \mathrm{O}_{10}$ & Emodin-1-glucoside (13) ${ }^{*}$ \\
\hline 18.86 & $231,278,482$ & $343 ; 299$ & $\mathrm{C}_{17} \mathrm{H}_{12} \mathrm{O}_{8}$ & Dermorubin (15) \\
\hline 20.23 & $229,285,452$ & $303 ; 239$ & $\mathrm{C}_{15} \mathrm{H}_{9} \mathrm{ClO}_{5}$ & 7-Cl-Emodin \\
\hline 23.03 & $211,283,431$ & $283 ; 240$ & $\mathrm{C}_{16} \mathrm{H}_{12} \mathrm{O}_{5}$ & Physcion (16) \\
\hline 26.28 & 263,484 & 770 & $\mathrm{C}_{22} \mathrm{H}_{22} \mathrm{O}_{12}$ & Dermocybin-1-glucoside (14) ${ }^{\#}$ \\
\hline \multicolumn{5}{|c|}{ Tapinella atrotomentosa, Figure 1, chromatogram $(370 \mathrm{~nm})$ and spectra C } \\
\hline 07.40 & 263,371 & $325.07 ; 307.06$ & $\mathrm{C}_{18} \mathrm{H}_{12} \mathrm{O}_{6}$ & Atromentin (17) \\
\hline
\end{tabular}



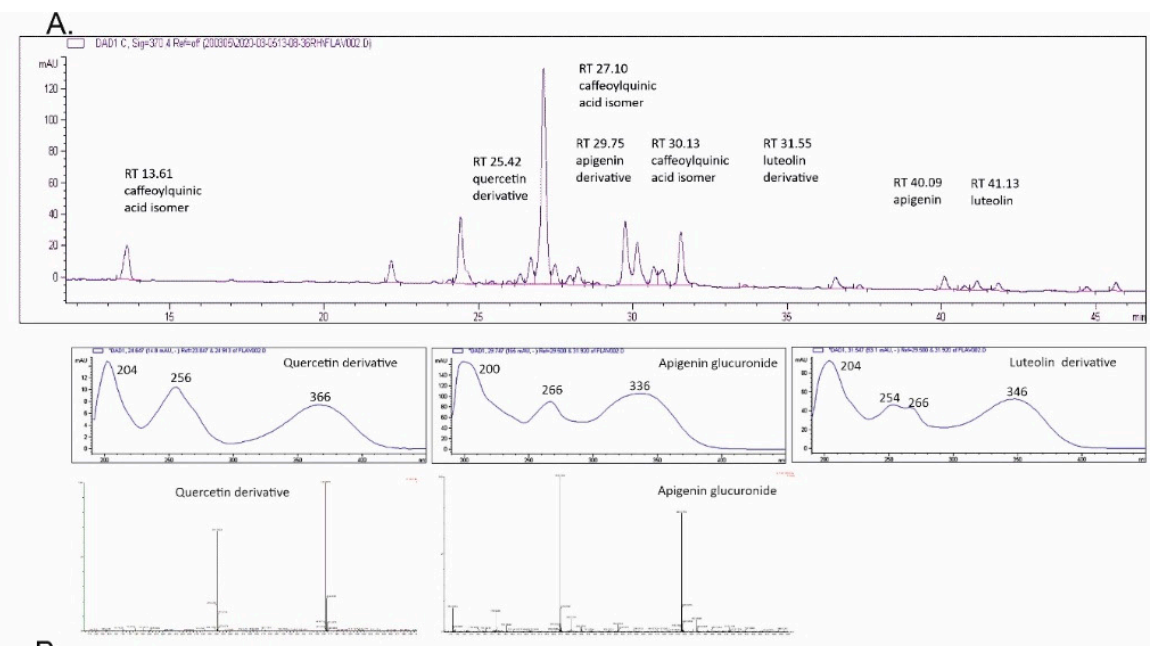

B.
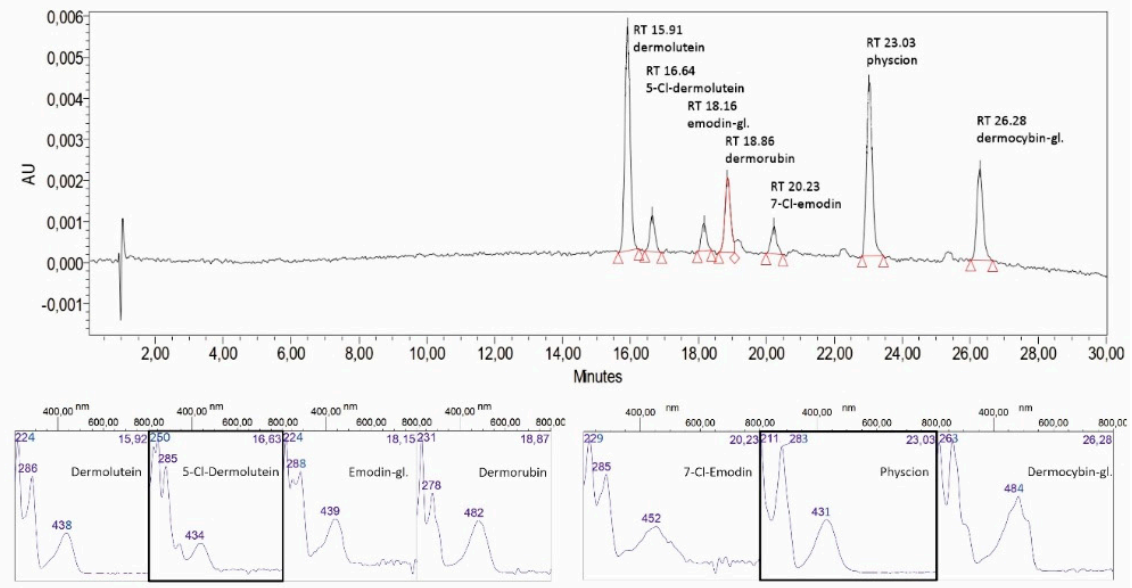

C

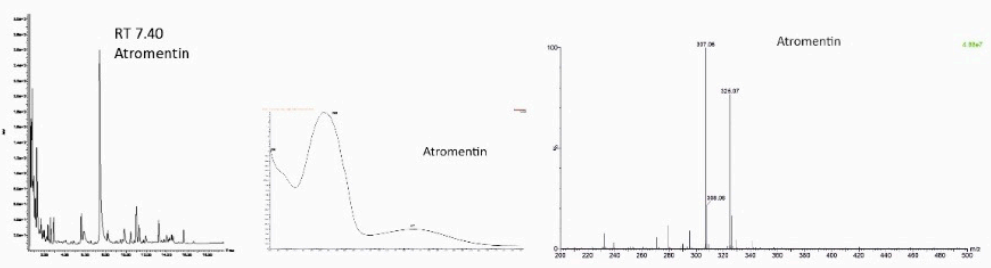

Figure 1. HPLC chromatogram, UV/Vis and MS spectra of the main compounds of (A) Tanacetum vulgare (HPLC detection at $370 \mathrm{~nm}$ ), (B) Cortinarius semisanguineus (HPLC detection at $440 \mathrm{~nm}$ ) and (C) Tapinella atrotomentosa (HPLC detection at $370 \mathrm{~nm}$ ) extracts. Detailed data is in Table 3.

In C. semisanguineus dermolutein, physcion, dermocybin-1-glucoside, and dermorubin were identified together with three other antraquinones and the results follow our previous findings [68]. In HPLC, T. atrotomentosa showed one major peak which was identified as atromentin with the UV/Vis and mass spectrometric data (Table 3).

The colours of the dyed woollen samples are shown in Table 2 and the colour fastness results in Table 4. The results presented in Table 4 show that mordant increases the stability of the dye structure, which can be seen from the higher light fastness values compared to the non-mordanted samples. The use of iron mordant gives slightly higher values, which can be explained by its ability to form stabilising coordination complexes [86]. Washing fastness tests reveal that staining is quite low, but highly basic $(\mathrm{pH} \sim 10)$ washing liquor results in colour changes that are particularly visible in yellow and red hues. In all cases, colour after washing was stronger than before, and its hue was different. This is due to bathochromic change of the dye molecule's absorption maxima as a result 
from the ionisation of the free $\mathrm{OH}$-groups. Metal complexes formed by $\mathrm{Al}^{3+}$ and $\mathrm{Fe}^{3+}$ ions stabilise the structure and decrease colour change as seen from their higher values.

Table 4. Colour fastnesses to light (scale 1-8) and washing (scale 1-5). LF = light fastness (200 h without side change), $\mathrm{Cc}=$ colour change, $\mathrm{s}=$ staining, $\mathrm{NM}=$ no mordant.

\begin{tabular}{ccccc}
\hline Dyeing & LF & \multicolumn{3}{c}{ Washing Fastness } \\
& \multicolumn{5}{c}{ Cc } & s, WO & s, CO \\
\hline Tanacetum & \multicolumn{4}{c}{} \\
\hline NM, direct dye & 6 & 1 & 5 & $4 / 5$ \\
Alum mordant & 7 & $3 / 4$ & 5 & 4 \\
FeSO4 mordant & 7 & $2 / 3$ & 5 & 4 \\
\hline Salix & & & & \\
\hline NM, direct dye & 5 & 1 & 5 & 5 \\
Alum mordant & 6 & $2 / 3$ & 5 & 5 \\
FeSO4 mordant & 6 & 2 & 5 & 5 \\
\hline Cortinarius & & & & \\
\hline NM, direct dye & 3 & $3 / 4$ & $4 / 5$ & $4 / 5$ \\
Alum mordant & 4 & 4 & $4 / 5$ & $4 / 5$ \\
FeSO4 mordant & 5 & 4 & $4 / 5$ & $4 / 5$ \\
\hline Tapinella & & & & \\
\hline NM, direct dye & 2 & 3 & 5 & $4 / 5$ \\
Alum mordant & 4 & $3 / 4$ & 5 & $4 / 5$ \\
FeSO 4 mordant & 5 & $3 / 4$ & 5 & 5 \\
\hline
\end{tabular}

\subsection{Toxicity}

In the HTD tests, the limit of significant toxicity was placed at $\mathrm{EC}_{50}$ [52]. Thus, if over $50 \%$ of the exposed cells exhibited changes in cell morphology and viability (i.e., HTD value was 3 or 4), the influence of the sample was interpreted as being toxically significant. HTD value 2 was regarded as the result of a low toxic effect, and subsequently, the value of 1 as a non-toxic, harmless effect.

EtOH controls $(0.5,1,2,4 \%)$ in parallel were first tested on cells. It was found that no cell changes were observed (i.e., $\mathrm{HTD}$ values 0 ) at the $\mathrm{EtOH}$ concentrations up to $2 \%$ after exposure of $24 \mathrm{~h}$. However, when the $\mathrm{EtOH}$ concentration rose to its highest $(4 \%)$, one of the parallel samples had undergone mild cell changes $(<25 \%)$, indicating non-toxic, harmless effect.

After longer exposure time $(72 \mathrm{~h}$ ) with similar parallel $\mathrm{EtOH}$ concentrations up to $2 \%$, no cell changes were observed. However, with the highest $\mathrm{EtOH}$ concentration $(4 \%)$, the quantity of cell changes rose to the next level $(<25 \%)$, similarly than in the shorter time of exposure, but now both of the parallel samples had undergone changes, indicating non-toxic effect.

Although the quantity of cell changes $(<25 \%)$ with the HTD value 1 had been regarded as harmless by Klemola (2008), excluding any possible toxicity caused by the solvent was wanted, and therefore, EtOH concentrations $0.5,1$ and $2 \%$ were selected for further inspections.

\subsubsection{The Effect of EtOH Concentration on the Cell Morphology and Viability}

$\mathrm{EtOH}$ extracts were diluted to the concentrations of $0.5,1$ and $2 \% \mathrm{EtOH}$ with $\alpha$-MEM. The results showed the stronger the $\mathrm{EtOH}$ concentration was, the higher the amount of change in the morphology and the loss of viability\% (HTD value) in exposed cells, showing a highly significant correlation (Figure 2a). 


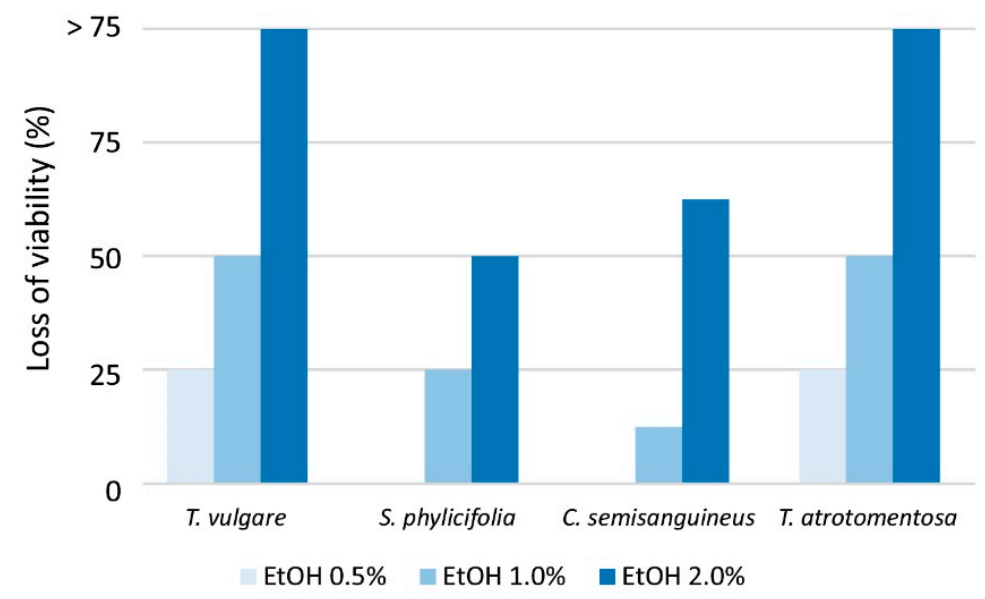

a

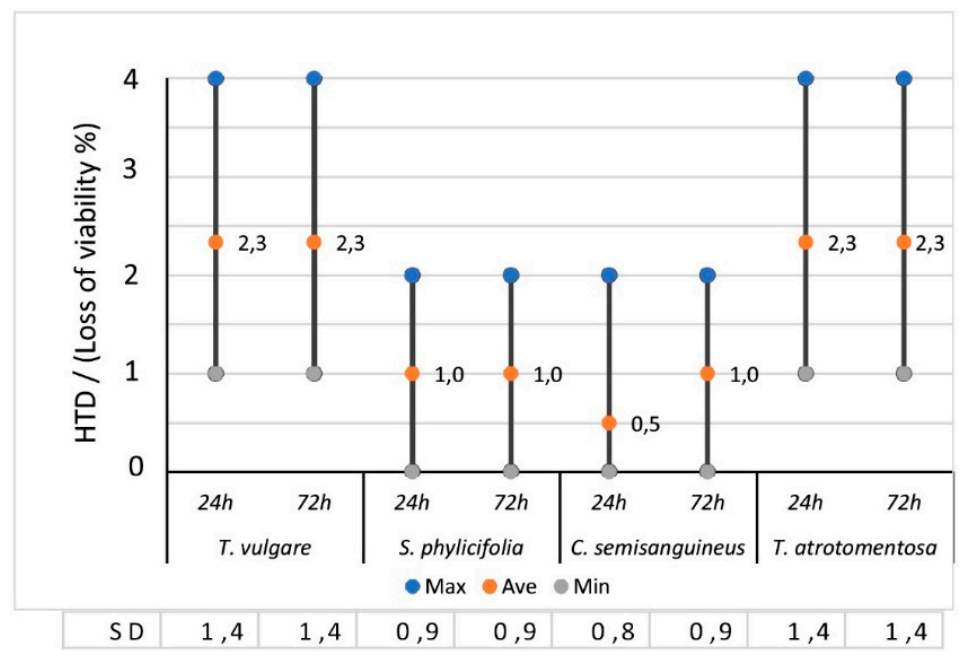

b

Figure 2. The Toxicity of the Plant and Fungal Materials. (a) The effect of EtOH concentration on the average changes in the morphology and the loss of viability \% for the different EtOH dilutions. Samples of $24 \mathrm{~h}$ and $72 \mathrm{~h}$ exposure times are included. $\left(\mathrm{r}_{\mathrm{s}}=0.863, p<0.0005, \mathrm{n}=192\right)$. (b) The effect of time on the HTD values (changes in morphology and loss of viability (\%) where $1<25 \%, 2=-50 \%, 3=-75 \%$, $4>75 \%$ ). The ranges and average values are marked in the columns and standard deviations (SD) at the bottom. The results $(n=195)$ include EtOH concentrations of $0.5,1$ and $2 \%$.

\subsubsection{The Toxicity of the Plant and Fungal Materials}

None of the dye sources (Tanacetum, Salix, Cortinarius and Tapinella) were significantly toxic when the $\mathrm{EtOH}$ concentration was $1 \%$ or less. This indicated that $1 \% \mathrm{EtOH}$ contained extracted compounds in the amounts and composition, which was some kind of threshold value. The changes in the cell morphology and the losses of viability, which the diluted $1 \%$ EtOH extract induced, were $<50 \%$ (i.e., HTD value was 2 at the maximum).

According to our results, Tanacetum and Tapinella extracts were the most toxic samples. If the extracts were diluted to $2 \% \mathrm{EtOH}$, they caused changes in the cell morphology in the quantity of $75 \%$ (i.e., HTD values were 4), indicating significant toxicity (Figure 2a).

Time did not have any effect on toxicity i.e., the cell morphological changes were at the same quantities (Figure $2 \mathrm{~b}$ ) when comparing exposure times of $24 \mathrm{~h}$ and $72 \mathrm{~h}$ of plant and fungal material. However, there were slightly more cell changes with increased exposure time caused 
by Cortinarius extracts, but the difference was statistically insignificant compared with the other samples (Mann-Whitney U-test, $p>0.05, \mathrm{n}=44$ ).

\subsubsection{The Toxicity of the Undyed Fabrics}

Unmordanted and mordanted undyed fabric samples diluted to $0.5 \% \mathrm{EtOH}$ did not show any changes indicating non-toxicity (i.e., HTD value was 0 ). However, when these samples were diluted to $1 \%$ and $2 \% \mathrm{EtOH}$, exposed cells showed changes in morphology and viability in the quantity of $<50 \%$, indicating a low toxic effect at the maximum.

A longer time of exposure slightly increased changes in exposed cells, but the results were still below toxicity, i.e., average HTD values were 1.0 after exposure of $24 \mathrm{~h}$, and 1.3 after $72 \mathrm{~h}$ (Figure 3). The difference between the two timespans was statistically insignificant (Mann-Whitney U-test, $p>0.05, \mathrm{n}=24)$.

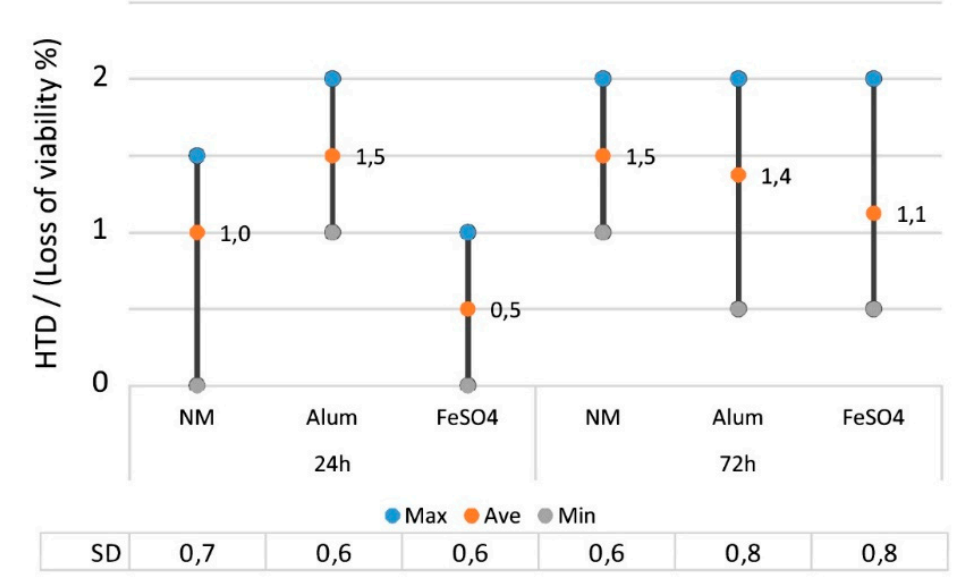

Figure 3. The effect of time on the changes in the morphology and the loss of viability (\%) for the mordanted but undyed fabrics, where the HTD value of 1 indicated $<25 \%$ loss of viability and 2 between $25-50 \%$. The results contain the values of 1 and $2 \% \mathrm{EtOH}$ dilutions. $\mathrm{NM}=$ no mordant, $\mathrm{SD}=$ standard deviation.

Iron $\left(\mathrm{FeSO}_{4}\right)$ mordanted fabric samples induced the least cell changes, as HTD values were 2 at the maximum indicating from non-toxic to low toxic effects, but the differences compared to alum $\left(\mathrm{KAl}\left(\mathrm{SO}_{4}\right)_{2}\right)$ or unmordanted samples were insignificant (Kruskal-Wallis-test, $X^{2}=3.37, p>0.05$, $\mathrm{n}=24$ ) (Figure 3).

\subsubsection{The Toxicity of the Dyed Fabrics}

The CIELab values of the colours obtained from dyeing are shown in Table 2. The dyed fabric samples induced slightly more changes to exposed cells than undyed fabric samples, but the differences were insignificant (Kruskal-Wallis test, $\left.X^{2}(1.120)=1.339, p>0.05(p=0.247), \mathrm{n}=360\right)$ (Figure 4).

When the dyed fabrics were diluted to $0.5 \%$ or $1 \% \mathrm{EtOH}$, their effect on the morphology and viability of the exposed cells was $<25 \%$, i.e., HTD values were 1 at the highest, indicating the diluted dyed fabric samples were non-toxic.

All the dyed fabric samples caused changes on exposed cells when they were diluted to $2 \% \mathrm{EtOH}$. In that case, at least one of the two parallel samples induced $25-50 \%$ losses of morphology and cell viability, i.e., HTD values were 2 , indicating a non-significant but still low toxicity.

Iron mordanted dyed samples induced the least changes on exposed cells i.e., low toxic effects at the maximum, after exposure of $24 \mathrm{~h}$. However, after exposure of $72 \mathrm{~h}$, the differences between iron mordanted dyed samples and undyed controls became smaller, and the iron mordanted samples obtained HTD values similar to all others (Figure 4). 

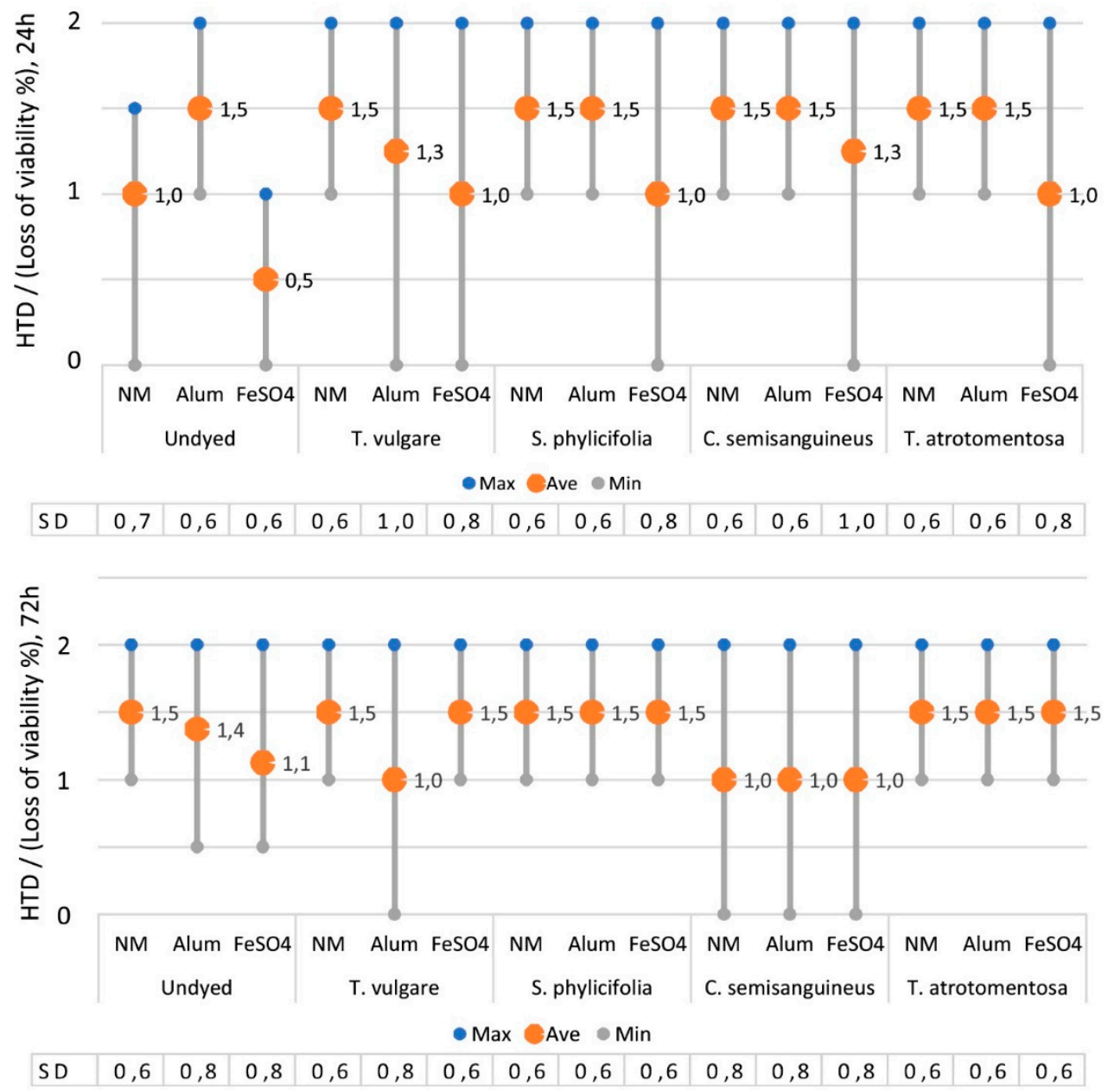

Figure 4. The effect of dye source, mordant and time on the HTD values (changes in morphology and loss of viability\%) after $24 \mathrm{~h}$ (above) and $72 \mathrm{~h}$ (below) exposure times. EtOH dilutions of $1 \%$ and $2 \%$ are included $(\mathrm{n}=152)$. NM = no mordant, $\mathrm{SD}=$ standard deviation.

In the case when all the samples were examined, it was observed that the dyed fabrics induced slightly more changes to exposed cells than the undyed fabrics. Those changes indicated harmless, non-toxic, or low toxic effects at the maximum. However, the difference between these two groups was statistically insignificant (Kruskal-Wallis test, $X^{2}=1.34, p>0.05, \mathrm{n}=192$ ).

The length of the exposure time did not increase the difference in inducing cell changes caused by the dyed fabrics compared to the undyed controls.

Interestingly, for diluted undyed fabric samples and diluted Tanacetum-, Salix- and Tapinella-dyed fabric samples, effects on exposed cells increased with time, whereas for Cortinarius the situation was contrary: The longer the exposure time, the fewer changes were observed in the exposed cells. This was shown by the lower HTD values after the exposure of $72 \mathrm{~h}$.

\subsubsection{The Effect of Mordant on the Toxicity}

The effect of the mordant on the colour can be seen of the CIELab values in Table 2. Iron mordant obviously darkened colours.

The analysis showed that iron mordant induced the fewest changes to exposed cells compared to other mordants, as shown by the lowest HTD values (Figure 4). In all the samples there was slightly 
more variation (max and min values) observed after the exposure time of $24 \mathrm{~h}$ than $72 \mathrm{~h}$, showing time evening out the differences.

Unmordanted but biocoloured fabrics (Tanacetum, Salix and Tapinella) did not produce any difference in the HTD values at either exposure times; nor did they produce any difference compared to the unmordanted undyed fabric sample. When examining the HTD values of unmordanted samples after the exposure of $24 \mathrm{~h}$, it was observed that the dyed fabrics received slightly higher values than the undyed controls, but after $72 \mathrm{~h}$, the differences between dyed and undyed fabrics had disappeared. The only exception was Cortinarius, which received lower HTD values after $72 \mathrm{~h}$ than $24 \mathrm{~h}$, with all mordants.

The alum mordanted Tanacetum fabric samples differed slightly from other dyed samples and the undyed controls by causing fewer cell changes at both exposure times, the difference being statistically insignificant.

The samples that were mordanted with iron and dyed with different biocolourants did not differ significantly from each other.

When examining differences between the mordants, it was observed that iron induced the least change in exposed cells, although the differences compared to other mordants were insignificant (Kruskal-Wallis, $X^{2}=3.33, p>0.05, \mathrm{n}=120$ ). The most changes were observed after the exposure of $24 \mathrm{~h}$, but the Kruskal-Wallis test revealed that the differences between all the mordants were insignificant $\left(X^{2}=5.73, p>0.05, \mathrm{n}=60\right)$.

\section{Discussion}

The sample extracts $(99.5 \% \mathrm{EtOH})$ were diluted to three EtOH concentrations $(0.5,1.0,2.0 \%)$ and the results showed that the higher the $\mathrm{EtOH}$ concentration, the more changes in the morphology and viability of exposed cells were observed. This was likely because of the increase in the concentrations of compounds extracted with $\mathrm{EtOH}$ from the plant and fungal material.

With the lowest $\mathrm{EtOH}$ concentration, no cytotoxicity was observed, indicating that the type and number of toxicity-inducing compounds in the sample was low. However, further studies would be needed to analyse these compounds, their character and behaviour more precisely.

Both the plant and fungal extracts and dyed fabrics of Tanacetum and Tapinella showed the most change in the morphology and viability of the exposed cells. If their extracts were diluted to $2 \% \mathrm{EtOH}$, the changes were toxically significant.

The studied sample of T. vulgare (Finland) was a camphor chemotype (71\% camphor), but had no quantifiable thujones $[18,41]$, which are regarded at high concentrations to exhibit toxicity [40]; so, we suppose there are some other components than thujones that are responsible for the observed low to moderate cytotoxicity. Furthermore, the tansy used in this research was collected and dried years ago and long storage time may have affected the composition and content of colourants and other compounds. Our qualitative HPLC-UV/Vis-MS analysis showed that the majority of the secondary compounds had preserved well over the years.

According to previous studies that used the same solvent as we did, i.e., $\mathrm{EtOH}$, or similar EtOH: $\mathrm{H}_{2} \mathrm{O}$, extracts obtained from the aerial parts of Tanacetum species contained secondary metabolites from the groups of sesquiterpene, non-volatile sesquiterpene lactones, coumarins, phenolic acids, and flavonoids [49,87-89]. Previously, the essential oils of tansy have shown cytotoxicity. The oil distilled from the aerial parts of T. vulgare (Canada) with camphor (31\%), borneol (15\%) and 1,8-cineole (i.e., eucalyptol) (11\%) as the major components were slightly cytotoxic against human healthy cell line WS1 and human keratinocytes (HaCaT). Furthermore, its minor components, $\alpha$-humulene $(0.21 \%)$ and caryophyllene oxide $(1.13 \%)$, possessed a moderate cytotoxicity against both of these [90].

The recent results [44] strongly implied that the toxicity of T. vulgare ( $\beta$-thujone chemotype) essential oil, obtained from its aerial parts with hydrodistillation, should not be associated exclusively with thujones. The tests using the Artemia salina model indicated that some other (minor) constituents of the oil were responsible for the observed more pronounced acute toxicity. For example, sabinene, 
terpinen-4-ol and caryophyllene oxide showed very strong negative correlations $(\mathrm{r}>-0.8)$ with the live nauplii after $48 \mathrm{~h}$, while all other constituents (e.g., linalool, intermedeol, sabinyl acetate) showed strong $(r>-0.6)$ negative correlations [44]. Previously, it has been shown that a linalool rich oil was more toxic in this brine-shrimp bioassay than the sample that did not contain this monoterpene alcohol [44].

Rosselli and coworkers [42] isolated five sesquiterpene lactones with the eudesmanolides skeleton from the dried flowers of T. vulgare ssp. siculum (Guss). All of them (douglanin, ludovicin B, ludovicin A, $1 \alpha$-hydroxy-1-deoxoarglanine, 11,13-dehydrosantonin) had high time- and concentration-dependent cytotoxic activity against in vitro cultured cancer and healthy cell lines (V79379A), being more effective against the latter ones.

As far as we are aware, there have been no previous cytotoxicity studies concerning T. atrotomentosa, which would have shown significant toxicity when the extract was diluted to $2 \% \mathrm{EtOH}$. Despite this, its chemistry holds great potential, as atromentin, the central terphenylquinone intermediate of a large family of homobasidiomycete secondary metabolites, represents the generic precursor molecule for the entire terphenylquinone and pulvinic acid family of colourants.

Atromentin may be modified by oxidative ring splitting into atromentic acid (yellow), or by dihydroxylation and symmetric heterocyclisation to thelephoric acid; or by reduction and esterification to produce leucomentins, which can upon saponification, release osmundalactones [91].

The terphenylquinone compounds have gained pharmaceutical attention due to their multiple bioactivities and have been produced under laboratory conditions [91]. The significant cytotoxicity we found in these preliminary studies would need further research. T. atrotomentosa holds great potential as a source of colourants, but also due to its manifold other properties. In recent years, a lot of effort has been focused on the development of cultivation of fungi for colourant production [11,92,93].

For Salix and Cortinarius, the HTD values caused by their extracts and dyed fabrics were quite similar. Both showed low cytotoxicity when diluted to $2 \% \mathrm{EtOH}$. The observed toxicity changes did not alter after exposure of $72 \mathrm{~h}$.

The compounds and interactions that lie behind the observed toxicity of Cortinarius extracts are probably due to anthraquinones, the chemistry and toxicity of which were found in previous studies, are presented in Section 1.5. Natural anthraquinones are interesting compounds in many applications and they need more detailed studies.

The low cytotoxicity of Salix extracts was presented for the first time. Generally, the extracts of Salix bark have been regarded as being safe, although sensitive individuals may get allergic reactions due to salicylates. Studies have also shown that there are other salicin-related compounds that contribute to various effects, which may also concern cytotoxicity [57].

Textile production procedures are complex. During the procedures, many different auxiliary chemicals are used, and extracts may contain remnants of them. In our study, the undyed fabrics were not interpreted as being cytotoxic; however, they caused effects from non-toxic to low toxic, depending on the concentration of EtOH, for both unmordanted and mordanted fabrics, indicating that it is also important to analyse the toxicity of the undyed fabric itself.

All unmordanted and alum $\left(\mathrm{KAl}\left(\mathrm{SO}_{4}\right)_{2}\right)$ and iron $\left(\mathrm{FeSO}_{4}\right)$ mordanted fabrics showed slight changes $(\leq 50 \%)$ in cell structures when diluted to 1 or $2 \% \mathrm{EtOH}$ and interpreted toxically insignificant changes. The study showed that iron mordanted fabric samples induced the least cell changes, but the differences compared to alum $\left(\mathrm{KAl}\left(\mathrm{SO}_{4}\right)_{2}\right)$ or unmordanted samples were insignificant. The reason for this is not known, but leucomentins of Tapinella may act as iron chelators [94], and condensed tannins of Salix species form complexes with metal ions [60].

In these cell tests, the concentration of plant/fungal material was approx. $50-800 \mu \mathrm{g} / \mathrm{mL}$ of $\alpha$-MEM. If organic material contains approx. $4 \%$ of biocolourants, a maximum of $2-32 \mu \mathrm{g}$ pure dye/mL of $\alpha$-MEM was used in the cell tests. This is considerably less compared with Klemola [52] who used 50-1600 $\mu \mathrm{g}$ pure synthetic dye/mL medium in the studies. In the future studies, higher concentrations of plant/fungal material should be tested. 
Using pure dyes in tests would give less ambiguous results. On the other hand, it is difficult to predict the toxicity of a dyed material from just testing the dye, because one chemical itself may be non-toxic but the chemicals and materials together may have a totally different effect [95]. Also, differences exist between a plant material extract which contains all soluble compounds and an extract from a dyeing when only the portion of substances which had been adsorbed during dyeing and released in later extraction are present. Development of biocolourants would be more economic if crude extracts were used instead of fractions or purified compounds. If additional values of biocolourant are to be developed, it is essential to consider whether the product would be purified or a mixture, as in the purification step, activities may be lost or decreased [96].

The cell tests can give information about the potential toxicity of extracts from textile materials. However, the cell type and test method used have an impact on how the analysis results may be interpreted. Only one type of cell, Hepa-1, was used in this research, and conclusions are only directly applicable to this cell type. The cases in which one cell line analysis shows slight cytotoxicity may appear to be harmless to humans. To draw a more reliable picture, several different cell lines should be used, and the total impact evaluated based on all results. Nonetheless, Hepa-1 cells have been observed to predict potential cytotoxicity in humans better than rat cells [52]. Hepa-1 cytotoxicity test can give useful information about the overall toxicity of extracts from textiles and can help in the development of safe textile products [97].

When considering the harmful effects of dyes, discussion is most often focused on environmental effects and the elimination of dyes from textile effluents, instead of the direct influence of textile dyes on human health [5]. The biocolourants are biodegradable, but their production, usage at a larger scale, and safety needs much more research.

We tested four extracts of plant/fungal sources and dyed fabrics to answer the question whether it is safe to wear natural dyed textile. The amounts of natural colour compounds in textile after dyeing are low. Washing fastness tests reveal that minimal amounts of colourants were removed during these simulated standardised use phases. This preliminary study showed that risk for harmful effects of natural dyes when wearing textiles are low among the tested dye sources.

\section{Materials and Methods}

\subsection{Plant and Fungal Material}

Tansy flower heads (Tanacetum vulgare L.), obtained from Natural Resources Institute Finland (Jokioinen, Finland), were harvested in 2000. The plant previously studied by Keskitalo [18] was classified as camphor chemotype. Flowers were dried and stored in the dark at room temperature (RT) until used in June 2010. A 1:1 mass ratio of dried flower heads to textile material was used for the dye liquor.

Willow (Salix phylicifolia L.) was gathered from Sipoo, Finland, in May 2008. Bark was separated and left to dry in a dark place at RT until used in June 2010. To prepare the dye liquor, a 5:1 mass ratio of dried bark to textile material was used. The bark was soaked in water for 2 days before heated extraction.

Fruiting bodies of surprise webcap [Cortinarius semisanguineus (Fr.) Gillet] were collected from Jyväskylä, Finland, in 2005. They were dried at $60{ }^{\circ} \mathrm{C}$ and stored in a dark place at RT until used in June 2010. To prepare the dye liquor, a 1:1 mass ratio of dried fungi to textile material was used.

Velvet roll-rims [Tapinella atrotomentosa (Batsch.) Šutara] were gathered from Espoo, Finland, in September 2009 and deep-frozen until used in June 2010. To prepare the dye liquor, a 10:1 mass ratio of defrosted fungi to textile material was used.

The preparation of dye liquors followed the traditional dyeing recipes in which 1:1 dried plant/fungi for textile material and 10:1 fresh fungi/textile material were used. For Salix, a five times greater amount of material was used to obtain an identically deep colouration of textile [13]. 


\subsection{Methods for Compound Identification}

Qualitative analysis of the main colourants of each studied species was performed using HPLC combined with UV/Vis and MS detections.

The phenolic compunds in Tanacetum flowers were analysed by HPLC-DAD and UHPLC-QTOF MS/MS analytical equipments and methods described in Pihlava et al. [98]. Briefly, $300 \mathrm{mg}$ of ground sample was extracted with $10 \mathrm{~mL}$ of $\mathrm{MeOH}$ for $1 \mathrm{~h}$ in an ultrasonic water bath. An aliquot of extract was filtered through a $0.20 \mathrm{~mm}$ membrane filter into an autosampler vial for the analysis.

Anthraquinones of Cortinarius were analysed with methods described earlier by Vanden Berghe et al. [99].

The ground fungal material of Tapinella $(100 \mathrm{mg}$ ) was extracted with $1 \mathrm{~mL}$ of $\mathrm{MeOH}$ using ultrasonication for $15 \mathrm{~min}$ where after centrifuged and the liquid phase was transferred to another tube. The material was re-extracted twice with $1 \mathrm{~mL}$ of $\mathrm{MeOH}$; extracts were combined and evaporated to dryness. The samples were reconstituted in $0.2 \mathrm{~mL}$ of $50 \%$ aqueous $\mathrm{MeOH}$. Analysis was performed on an Acquity UHPLC system (Waters, Milford, MA, USA) equipped with a Waters Synapt G2-S MS system and Waters Photodiode Array (PDA) Detector. The analytical column ACQUITY UPLC BEH HSS T3 $(1.8 \mu \mathrm{m} 2.1 \times 100 \mathrm{~mm})$ was kept at $30^{\circ} \mathrm{C}$. The experiment was carried out at a flow rate of $0.4 \mathrm{~mL} / \mathrm{min}$ with mobile phase $\mathrm{A}(0.1 \%$ formic acid in water $)$ and $\mathrm{B}(0.1 \%$ formic acid in $\mathrm{MeOH})$. The gradient elution started at $20 \%$ B (0-0.2 min), was increased linearly to $100 \%$ B within $28 \mathrm{~min}$ and after this returned within $0.1 \mathrm{~min}$ to initial percentage where it was maintained for $2 \mathrm{~min}$. The injected sample amount was $2 \mu \mathrm{L}$. Mass spectrometry was carried out using electrospray ionization (ESI) in positive polarity, and leucine enkephalin was used as the lock spray reference compound. The capillary voltage was $2.0 \mathrm{kV}$, cone voltage $40 \mathrm{kV}$, source temperature $150^{\circ} \mathrm{C}$, and desolvation temperature $500^{\circ} \mathrm{C}$. The cone and desolvation gas flow were set at $60 \mathrm{~L} / \mathrm{h}$ (nitrogen) and $1000 \mathrm{~L} / \mathrm{h}$ (nitrogen), respectively. The data was collected at a mass range of $m / z 50-800$ with a scan duration of $0.2 \mathrm{sec}$. The PDA detection wavelength range was $200-500 \mathrm{~nm}$.

\subsection{Dyeing of Fabric Samples and the Colour Fastness Testing}

Technical grade alum $\left(\mathrm{KAl}\left(\mathrm{SO}_{4}\right)_{2}\right)$ and $\mathrm{FeSO}_{4}$ (TetriDesign, Helsinki, Finland) and tap water (pH 7.8; Helsinki Region Environmental Services Authority HSY, Helsinki, Finland) were used for dyeing. Pre-mordanting and dyeing were performed in an Original Hanau Linitest machine (Hanau, Germany). The colour was measured as CIE L*, a* and b* values [100] using a Konica Minolta (Tokyo, Japan) CM-2600d spectrophotometer $\left(\mathrm{D} 65,10^{\circ}\right)$. Unbleached $100 \%$ wool fabric (plain weave, warp and weft densities 6.5 yarns $/ \mathrm{cm}, 84 \mathrm{~g} / \mathrm{m}^{2}$ ) (HAMK/Wetterhof, Hämeenlinna, Finland) was made of the SportLoden yarn (Nm 28/2, with Öko-Tex 100 and Bluesign labels) (Schoeller, Germany).

To prepare the dye extracts, the amount of dried or defrosted plant or fungal material, as in Section 4.1, was weighed, chopped or crushed, and boiled in water covering the organic material. After boiling $\left(80-90^{\circ} \mathrm{C}, 60 \mathrm{~min}\right)$, the extract was filtered. Organic material was discarded and the filtrate used as a dye liquor.

The fabric samples (á $20 \mathrm{~g}$ ) were pre-mordanted with $10 \%$ on the weight of the fibre alum or $2 \%$ $\mathrm{FeSO}_{4}$ in a 1:40 material to liquor ratio. The mordant was diluted in water, wetted fabric was added and the vessel closed. The temperature was increased to $80^{\circ} \mathrm{C}$ and held there for $60 \mathrm{~min}$, continuously agitating the liquid. The samples were squeezed, left to dry at RT and stored in the dark until used. The $\mathrm{pH}$ for alum mordant liquor was 3.3-3.9 and for $\mathrm{FeSO}_{4}$ 4.5-5.3. The samples without mordant were treated similarly as the pre-mordanted samples.

The volume of the prepared dye extract was measured, and water was added to meet the 1:20 ratio for dyeing. Pre-mordanted samples were dyed at $90{ }^{\circ} \mathrm{C}$ for $60 \mathrm{~min}$ and then rinsed until no colour was observed in the water. The samples were left to dry at RT. The colour of each sample was measured as CIELab coordinates $\left(\mathrm{L}^{*}, \mathrm{a}^{*}, \mathrm{~b}^{*}\right)$ (Table 2$)$. $\mathrm{L}^{*}$ obtains values from zero for black to 100 for white; $a^{*}>0$ describes the redness, $a^{*}<0$ the greenness, $b^{*}>0$ the yellowness, and $b^{*}<0$ the 
blueness of the colour [100]. Colour fastness to light and laundering were studied according to the ISO 105-B02/A1-1994 and ISO 105-C06-1997 standards, respectively (Table 4).

\subsection{Preparation of Plant, Fungal and Fabric Extracts for Toxicity Testing}

Plant or fungal material was ground in a mortar (Tanacetum and Cortinarius) or cut into small pieces (Salix and Tapinella) and $1.5 \mathrm{~g}$ was placed in a $100 \mathrm{~mL}$ flask; $37.5 \mathrm{~mL} \mathrm{EtOH} \mathrm{(99.5 \% ,} \mathrm{Altia,} \mathrm{Helsinki,}$ Finland) was added and the materials were extracted for $24 \mathrm{~h}$ at RT. Thereafter, the extract was filtered and refrigerated until use. The colour of the Tanacetum extract was light green, Salix bright green, Cortinarius orange, and Tapinella black.

The dyed woollen fabrics and undyed controls were cut into $1 \mathrm{~cm} \times 1 \mathrm{~cm}$ pieces and treated similarly to the plant/fungal samples.

\subsection{Cytotoxicity Assays}

The cell tests were performed as described earlier [53,101]. The effects of each sample extract on the morphology and viability of the cells were evaluated using phase contrast microscopy by observing possible alterations in cell shape, e.g., cell rounding, swelling, cell shrinkage, vacuolization, growth inhibition, attachment, cell lysis, and cell death. Hepa-1 cells containing cytochrome P4501A (Department of Physiology, University of Kuopio, Kuopio, Finland) from mouse liver were used in HTD tests.

Cell culture reagents were $\alpha$-MEM (Minimum Essential Medium) without glutamine, endotoxin-free FBS (Fetal Bovine Serum), penicillin-streptomycin solution 100×, L-glutamine 100× (200 mM), PBS (Phosphate-Buffered Saline, pH 7.2) 10× without $\mathrm{Ca}^{2+}$ and $\mathrm{Mg}^{2+}$, and trypsin $0.05 \% / E D T A$ (ethylenediaminetetraacetic acid) $0.02 \%$ in PBS (EuroClone, Milan, Italy).

$\mathrm{EtOH}$ was used as a solvent control in concentrations of $0.5,1$ and $2 \%$ and $\alpha-\mathrm{MEM}$ as a negative control and solvent medium. Hepa- 1 cells were grown in $\alpha$-MEM supplemented with $1 \%$ L-glutamine, $10 \%$ endotoxin-free FBS and 1\% penicillin-streptomycin solution.

A short-term cytotoxicity test was carried out in 96-well microplates. Hepa-1 cells were left to grow for 2-3 days in cell culture flasks. Erythrosin B (Sigma, Darmstadt, Germany) was used to release the cells from the flasks: a 1:4 dilution was prepared using a $20 \mu \mathrm{L}$ volume of cells and that of $80 \mu \mathrm{L}$ of Erythrosin B, which were adjusted to the concentration of $5 \times 10^{4}$ cells $/ \mathrm{mL}$. A volume of $200 \mu \mathrm{L}$ from this dilution was pipetted into each well, resulting in 10,000 cells/well. A Bürker counting chamber measured the number of cells and cell density in each well.

Cells were exposed to the extracts prepared as explained in Section 4.4. EtOH extracts were diluted to the concentrations of $0.5,1$ and $2 \%$ with $\alpha$-MEM and a sample $(200 \mu \mathrm{L})$ was pipetted in a well. Non-exposed cells with $\alpha$-MEM were used as negative controls. DNP $(2,4(\alpha)$-dinitrophenol, $\mathrm{pH}$ 2.8-4.7, Merck, Kenilworth, NJ, USA) was used as a positive control and was diluted in DMSO (dimethylsulphoxide, pH 2.8-4.7, Riedel-de Haën, Seelze, Germany). A stock solution of DNP $(100 \mathrm{mg} / \mathrm{mL}$ ) was diluted with $\alpha$-MEM to the concentrations of $0.5,0.05$ and $0.005 \mathrm{mg} / \mathrm{mL}$. All results were compared with the controls.

After exposures of 24 and $72 \mathrm{~h}$, the cells were washed twice with PBS-buffer. The possible alterations of cells were observed with phase-contrast microscopy and compared to the control cells, which were without exposure. The alterations were described and the quantity of changes was evaluated with a five- step-scale: (0) no changes, (1) $<25 \%$, (2) $25-50 \%$, (3) $50-75 \%$, and (4) $>75 \%$ of cells had changed.

Each plant, fungal and fabric sample was studied using 0.5, 1 and $2 \%$ concentrations of EtOH extracts diluted with $\alpha$-MEM and incubation times of $24 \mathrm{~h}$ and $72 \mathrm{~h}$ as two parallel samples in different places in the 96-well microplates. Four parallel wells were studied from each sample. The results of parallel wells were reported as a single value. These values (1-4) were the basis for the statistical analysis. For a few samples, two values were reported (e.g., 0/1); in these cases, the mean value (0.5) was used for statistical calculations. 


\subsection{Statistical Analyses}

The SPSS program (IBM SPSS Statistics for Windows, Version 24.0, Armonk, NY, USA) was used for quantitative data analysis. Statistical significance was placed at $p<0.05$. The differences were evaluated using non-parametric Kruskal-Wallis one-way analysis of variance and the Mann-Whitney U-test.

\section{Conclusions}

The dilution concentration was shown to be of high importance concerning the toxicity issue. The highest HTD values were observed when the samples were diluted to $2 \% \mathrm{EtOH}$ concentration, which is due to higher concentrations of compounds including biocolourants. EtOH was used because it dissolves polar and somewhat lipophilic biocolourants, as well as those of potential toxins. Pure $2 \%$ EtOH was observed as being harmless.

The most cytotoxic effects were induced by the extracts of Tanacetum and Tapinella. With $2 \% \mathrm{EtOH}$, the HTD values were at the highest 4 , which means that over $75 \%$ of the tested cells had changes in morphology and loss of viability, indicating significant toxicity; the extracts of Salix and Cortinarius induced barely perceptible cytotoxicity when diluted to the same EtOH concentration.

When examining all the data, Salix induced the least toxic effects of the tested biocolourant sources. Tanacetum showed some toxicity, but the effect declined when the time of exposure increased from $24 \mathrm{~h}$ to $72 \mathrm{~h}$. Interpretation of the results could be more feasible if there were standardised methods for biocolourant production, extraction and in vitro testing.

In this research, Salix and Cortinarius semisanguineus were at most mildly harmful. Tapinella atrotomentosa and Tanacetum vulgare induced the most changes. At the highest non-toxic EtOH concentrations $(2 \%)$, all dyed fabrics were interpreted as being not significantly toxic. It seems that biocolourants may be a less harmful alternative to dyes. In all, the cytotoxicity of samples dyed with natural dyes did not differ from untreated wool. When developing the larger scale utilisation of biocolourants, profound bioassays and chemical analyses are necessary from single purified compounds to track the possible hazardous pathways of dyes in the human metabolism and environment.

Author Contributions: Conceptualization, R.R. and A.P.; methodology, R.R., A.P. and U.H.; software, S.N., R.R., H.N., J.-M.P. and I.V.B.; validation, R.R., A.P. and S.N.; investigation, R.R., U.H., A.P., S.N., H.N., J.-M.P. and I.V.B.; resources, R.R. and A.v.W.; writing—original draft preparation, R.R. and A.P.; writing-review and editing, A.v.W.; visualization, R.R.; supervision, R.R. and A.v.W.; project administration, R.R.; funding acquisition, R.R. All authors have read and agreed to the published version of the manuscript.

Funding: This work was supported by Aino-Koti Foundation (2010) and the Strategic Research Council at the Academy of Finland [funding decision no. 327178, 2019].

Acknowledgments: We express our gratitude to the laboratory technician Riitta Venäläinen for skilful assistance in the different parts of this study. We also want to thank Leena Loukojärvi and Saara Hynninen for their work in the dyeing experiments.

Conflicts of Interest: The authors declare no conflict of interest. The funders had no role in the design of the study; in the collection, analyses, or interpretation of data; in the writing of the manuscript, or in the decision to publish the results.

\section{References}

1. Holkar, C.R.; Jadhav, A.J.; Pinjari, D.V.; Mahamuni, N.M.; Pandit, A.B. A critical review on textile wastewater treatments: Possible approaches. J. Environ. Manag. 2016, 182, 351-366. [CrossRef]

2. Hunger, K. (Ed.) Industrial Dyes: Chemistry, Properties, Applications; Wiley: Weinheim, Gemany, 2003.

3. Leme, D.M.; Primo, F.L.; Gobo, G.G.; Da Costa, C.R.; Tedesco, A.C.; De Oliveira, D.P.J. Genotoxicity assessment of reactive and disperse textile dyes using human dermal equivalent (3D cell culture system). J. Toxicol. Environ. Health A 2015, 78, 466-480. [CrossRef]

4. Oliveira, G.A.R.D.; Leme, D.M.; De Lapuente, J.; Brito, L.B.; Porredón, C.; Rodrigues, L.D.B.; Brull, N.; Serret, J.T.; Borràs, M.; Disner, G.R.; et al.; et al. A test battery for assessing the ecotoxic effects of textile dyes. Chem. Biol. Interact. 2018, 291, 171-179. [CrossRef] 
5. Tang, A.Y.L.; Lo, C.K.Y.; Kan, C. Textile dyes and human health: A systematic and citation network analysis review. Color. Tehnol. 2018, 134, 245-257. [CrossRef]

6. Wink, M. Plant secondary metabolism diversity, function and its evolution. Nat. Prod. Commun. 2008, 3, 1205-1216. [CrossRef]

7. Simmler, C.; Chen, S.-N.; Anderson, J.; Lankin, D.C.; Phansalkar, R.; Krause, E.; Dietz, B.; Bolton, J.L.; Nikolic, D.; Van Breeman, R.B.; et al. Botanical integrity: Part 2. Traditional and modern analytical approaches. Herbal. Gram. 2016, 109, 60-61.

8. Macheix, J.-J.; Fleuriet, A.; Billot, J. Fruit Phenolics; CRC Press: Boca Raton, FL, USA, 1990.

9. Guinot, P.; Roge, A.; Gargadennec, A.; Garcia, M.; Dupont, D.; Lecoeur, E.; Candelier, L.; Andary, C. Dyeing plants screening: An approach to combine past heritage and present development. Color. Technol. 2006, 122, 93-101. [CrossRef]

10. Lavola, A.; Maukonen, M.; Julkunen-Tiitto, R. Variability in the composition of phenolic compounds in winter-dormant Salix pyrolifolia in relation to plant part and age. Phytochemistry 2018, 153, 102-110. [CrossRef]

11. Caro, Y.; Venkatachalam, M.; Lebeau, J.; Fouillaud, M.; Dufossé, L. Pigments and colourant from filamentous fungi. In Fungal Metabolites; Mérillon, J.-M., Ramawat, K.G., Eds.; Springer: Cham, Switzerland, 2017; pp. 499-568.

12. Schweppe, H. Handbuch der Naturfarbstoffe; Ecomed: Landsberg/Lech, Germany, 1993.

13. Räisänen, R.; Primetta, A.; Niinimäki, K. Dyes from Nature; Archetype Publications: London, UK, 2016.

14. Palo, R.T. Distribution of birch (Betula spp.), willow (Salix spp.) and poplar (Populus spp.) secondary metabolites and their potential role as chemical defense against herbivores. J. Chem. Ecol. 1984, 10, 499-520. [CrossRef]

15. Németh, É.Z.; Héthelyi, É.; Bernáth, J. Comparison studies on Tanacetum vulgare L. chemotypes. J. Herbs Spices Med. Plants 1994, 2, 85-92. [CrossRef]

16. Goudarzi, T.; Saharkhiz, M.J.; Rowshan, V. Ontogenetic variation of essential oil content and constituents in tansy (Tanacetum vulgare L.). J. Appl. Res. Med. Aromat. Plants 2015, 2, 48-53. [CrossRef]

17. Zidorn, C. Seasonal variation of natural products in European trees. Phytochem. Rev. 2018, 17, $923-935$. [CrossRef]

18. Keskitalo, M. Exploring Biodiversity to Enhance Bioactivity in the Genus Tanacetum through Protoplast Fusion. Doctoral Dissertation, University of Helsinki, Helsinki, Finland, 1999. Available online: http: //urn.fi/URN:ISBN:951-45-8965-3 (accessed on 14 October 2019).

19. Hynninen, P.H.; Räisänen, R.; Elovaara, P.; Nokelainen, E. Preparative isolation of anthraquinones from the fungus Dermocybe sanguinea using enzymatic hydrolysis by the endogenous $\beta$-glucosidase. Z. Naturforsch. 2000, 55c, 600-610. [CrossRef]

20. Spitaler, R.; Schlorhaufer, P.D.; Ellmerer, E.P.; Merfort, I.; Bortenschlager, S.; Stuppner, H.; Zidorn, C. Altitudinal variation of secondary metabolite profiles in flowering heads of Arnica montana cv. ARBO. Phytochemistry 2006, 67, 409-417. [CrossRef]

21. Gaspar, H.; Moiteiro, C.; Turkman, A.; Coutinho, J.; Carnide, V. Influence of soil fertility on dye flavonoids production in weld (Reseda luteola L.) accessions from Portugal. J. Sep. Sci. 2009, 32, 4234-4240. [CrossRef]

22. Jaakola, L.; Hohtola, A. Effect of latitude on flavonoid biosynthesis in plants. Plant Cell Environ. 2010, 33, 1239-1247. [CrossRef]

23. Orians, C.M. Preserving leaves for tannin and phenolic glycoside analyses: A comparison of methods using three willow taxa. J. Chem. Ecol. 1995, 21, 1235-1243. [CrossRef]

24. Brondz, I.; Ekeberg, D.; Høiland, K.; Bell, D.S.; Annino, A.R. The real nature of the indole alkaloids in Cortinarius infractus: Evaluation of artifact formation through solvent extraction method development. J. Chromatogr. A 2007, 1148, 1-7. [CrossRef]

25. Saxena, S.; Raja, A.S.M. Natural dyes: Sources, chemistry, application and sustainability issues. In Roadmap to Sustainable Textiles and Clothing. Textile Science and Clothing Technology; Muthu, S.S., Ed.; Springer Science + Business Media: Singapore, 2014; pp. 37-80.

26. Derksen, G.C.H.; Naayer, M.; Van Beek, T.A.; Capelle, A.; Haaksman, I.K.; Van Doren, H.A.; De Groot, Æ Chemical and enzymatic hydrolysis of anthraquinone glycosides from madder roots. Phytochem. Anal. 2003, 14, 137-144. [CrossRef]

27. Jäger, I.; Hafner, C.; Welsch, C.; Schneider, K.; Iznaguen, H.; Westendorf, J. The mutagenic potential of madder root in dyeing processes in the textile industry. Mutat. Res. 2006, 605, 22-29. [CrossRef] 
28. Ford, L.; Rayner, C.M.; Blackburn, R.S. Degradation of lucidin: New insights into the fate of this natural pigment present in dyer's madder (Rubia tinctorum L.) during the extraction of textile artefacts. Dyes Pigments 2018, 154, 290-295. [CrossRef]

29. Yasui, Y.; Takeda, N. Identification of a mutagenic substance, in Rubia tinctorum L. (madder) root, as lucidin. Mutat. Res. 1983, 121, 185-190. [CrossRef]

30. Mouri, C.; Laursen, R. Identification of anthraquinone markers for distinguishing Rubia species in madder-dyed textiles by HPLC. Microchim. Acta 2012, 179, 105-113. [CrossRef]

31. Zhang, X.; Laursen, R. Application of LC-MS to the analysis of dyes in objects of historical interest. Int. J. Mass Spectrom. 2009, 284, 108-114. [CrossRef]

32. Kawasaki, Y.; Goda, Y.; Yoshihira, K. The mutagenic constituents of Rubia tinctorum. Chem. Pharm. Bull. 1992, 40, 1504-1509. [CrossRef] [PubMed]

33. Brown, J.P. A review of the genetic effects of naturally occurring flavonoids, anthraquinones and related compounds. Mutat. Res. 1980, 75, 243-277. [CrossRef]

34. Inoue, K.; Yoshida, M.; Takahashi, M.; Fujimoto, H.; Shibutani, M.; Hirose, M.; Nishikawa, A. Carcinogenic potential of alizarin and rubiadin, component of madder color, in a rat medium-term multi-organ bioassay. Cancer Sci. 2009, 100, 2261-2267. [CrossRef]

35. Fotia, C.; Avnet, S.; Granchi, D.; Baldini, N. The natural compound alizarin as an osteotropic drug for the treatment of bone tumors. J. Orthop. Res. 2012, 30, 1486-1492. [CrossRef]

36. Liktor-Busa, E.; Kovács, B.; Urbán, E.; Hohmann, J.; Ványolós, A. Investigation of Hungarian mushrooms for antibacterial activity and synergistic effects with standard antibiotics against resistant bacterial strains. Lett. Appl. Microbiol. 2016, 62, 437-443. [CrossRef]

37. Devrnja, N.; Anđelkovićb, B.; Aranđelovićc, S.; Radulovićc, S.; Sokovića, M.; Krstić-Miloševića, D.; Ristićd, M.; Ćalić, D. Comparative studies on the antimicrobial and cytotoxic activities of Tanacetum vulgare L. essential oil and methanol extracts. S. Afr. J. Bot. 2017, 111, 212-221. [CrossRef]

38. Béni, Z.; Dékány, M.; Kovács, B.; Csupor-Löffler, B.; Zomborszki, Z.P.; Kerekes, E.; Szekeres, A.; Urbán, E.; Hohmann, J.; Ványolós, A. Bioactivity-guided isolation of antimicrobial and antioxidant metabolites from the mushroom Tapinella atrotomentosa. Molecules 2018, 23, 1082. [CrossRef] [PubMed]

39. Greim, H. Aims and mission of regulatory toxicology. In Regulatory Toxicology; Schwenk, M., Reichl, F., Eds.; Springer Reference: Berlin/Heidelberg, Germany, 2014; pp. 3-20.

40. Abad, M.J.; Bermejo, P.; Villar, A. An approach to the genus Tanacetum L. (Compositae): Phytochemical and pharmacological review. Phytother. Res. 1995, 9, 79-92. [CrossRef]

41. Keskitalo, M.; Pehu, E.; Simon, J.E. Variation in volatile compounds from tansy (Tanacetum vulgare L.) related to genetic and morphological differences of genotypes. Biochem. Syst. Ecol. 2001, 29, 267-285. [CrossRef]

42. Rosselli, S.; Bruno, M.; Raimondo, F.M.; Spadaro, V.; Varol, M.; Koparal, A.T.; Maggio, A. Cytotoxic effect of eudesmanolides isolated from flowers of Tanacetum vulgare ssp. siculum. Molecules 2012, 17, 8186-8195. [CrossRef]

43. Uehara, A.; Akiyam, S.; Iwashina, T. Foliar flavonoids from Tanacetum vulgare var. boreale and their geographical variation. Nat. Prod. Commun. 2015, 10, 403-405. [CrossRef]

44. Radulović, N.S.; Genčić, M.S.; Stojanović, N.M.; Randjelović, P.J.; Stojanović-Radić, Z.Z.; Stojiljković, N.I. Toxic essential oils. Part V. Behaviour modulating and toxic properties of thujones and thujone-containing essential oils of Salvia officinalis L.; Artemisia absinthium L., Thuja occidentalis L. and Tanacetum vulgare L. Food Chem. Toxicol. 2017, 105, 355-369. [CrossRef]

45. Orians, C.M. The effect of hybridization in plants on secondary chemistry: Implications for the ecology and evolution of plant-herbivory interactions. Am. J. Bot. 2000, 87, 1749-1756. [CrossRef]

46. Hynninen, S. Tansy as a Dye Plant-Hue and Colour Fastness of Wool Dyed with Different Tansy Populations [in Finnish]. Master's Thesis, University of Joensuu, Savonlinna, Finland, 2009.

47. Horváth, G.; Turcsi, E.; Molnár, P.; Szabó, L.G.; Deli, J. Carotenoid content of the flower of tansy (Tanacetum vulgare L.). Planta Medica 2007, 73, 911. [CrossRef]

48. Wodjylo, A.; Oszmiański, J.; Czemerys, R. Antioxidant activity and phenolic compounds in 32 selected herbs. Food Chem. 2007, 105, 940-949. [CrossRef]

49. Mureşan, M.; Benedec, D.; Vlase, L.; Oprean, R.; Toiu, A.; Oniga, I. Screening of polyphenolic compounds, antioxidant and antimicrobial properties of Tanacetum vulgare from Transylvania. Studia UBB Chemia 2015, 1, 127-138. 
50. Chaturvedi, D. Sesquiterpene lactones: Structural diversity and their biological activities. In Opportunity, Challenge and Scope of Natural Products in Medicinal Chemistry; Tiwari, V.K., Mishra, B.B., Eds.; Research Signpost: Kerala, India, 2011; pp. 313-334.

51. Lahlou, S.; Tahraoui, A.; Israili, Z.; Lyoussi, B. Diuretic activity of the aqueous extracts of Carum carvi and Tanacetum vulgare in normal rats. J. Ethnopharmacol. 2007, 110, 458-463. [CrossRef] [PubMed]

52. Klemola, K. Textile toxicity. Cytotoxicity and Spermatozoa motility Inhibition Resulting from Reactive Dyes and Dyed Fabrics. Doctoral Dissertation, Department of Biosciences, University of Kuopio, Kuopio, Finland, 2008. Available online: http://urn.fi/URN:ISBN:978-951-27-1094-2 (accessed on 14 October 2019).

53. EURL ECVAM DB-ALM. DB-ALM Method Summary: Protein Determination Assays (Lowry, Kenacid Blue, Coomassie Blue). 2010. Available online: https://ecvam-dbalm.jrc.ec.europa.eu/methods-and-protocols/ method-summary/1555/protein-determination-assays-(lowry,-kenacid-blue,-coomassie-blue)-summary/ datasheet (accessed on 14 October 2019).

54. Lahlou, S.; Israili, Z.H.; Lyoussi, B. Acute and chronic toxicity of a lyophilised aqueous extract of Tanacetum vulgare leaves in rodents. J. Ethnopharmacol. 2008, 117, 221-227. [CrossRef] [PubMed]

55. Falchero, L.; Brown, R.H.; Mueller-Harvey, I.; Hanley, S.; Shield, I.; Karp, A. Condensed tannins in willow (Salix spp.): A first step to evaluate novel feeds nutritionally improved animal products. Grassl. Sci. Eur. 2011, 16, 434-436.

56. Tyśkiewicz, K.; Konkol, M.; Kowalski, R.; Rój, E.; Warmiński, K.; Krzyżaniak, M.; Gil, Ł.; Stolarski, M.J. Characterization of bioactive compounds in the biomass of black locust, poplar and willow. A review. Trees 2019, 33, 1235-1263. [CrossRef]

57. Shara, M.; Stohs, S.J. Efficacy and safety of white willow bark (Salix alba) extracts. Phytother. Res. 2015, 29, 1112-1116. [CrossRef]

58. Matyjaszczyk, E.; Schumann, R. Risk assessment of white willow (Salix alba) in food. EFSA J. 2018, 16 (Suppl. 1), e16081. [CrossRef]

59. Juntheikki, M.R.; Julkunen-Tiitto, R. Inhibition of $\beta$-glucosidase and esterase by tannins from Betula, Salix and Pinus species. J. Chem. Ecol. 2000, 26, 1151-1165. [CrossRef]

60. Sulima, P.; Krauze-Baranowska, M.; Przyborowski, J.A. Variation in the chemical composition and content of salicylic glycosides in the bark of Salix purpurea from natural locations and their significance for breeding. Fitoterapia 2017, 118, 118-125. [CrossRef]

61. Schofield, P.; Mbugua, D.M.; Pell, A.N. Analysis of condensed tannins: A review. Anim. Feed Sci. Technol. 2001, 91, 21-40. [CrossRef]

62. Jürgenliemk, G.; Petereit, F.; Nahrstedt, A. Flavan-3-ols and procyanidins from the bark of Salix purpurea L. Pharmazie 2007, 62, 231-234.

63. Dou, J.; Xu, W.; Koivisto, J.J.; Mobley, J.K.; Padmakshan, D.; Kögler, M.; Xu, C.; Willför, S.; Ralph, J.; Vuorinen, T. Characteristics of hot Water Extracts from the Bark of Cultivated Willow (Salix sp.). ACS Sustain. Chem. Eng. 2018, 6, 5566-5573. [CrossRef]

64. Steglich, W.; Lösel, W.; Austel, V. Pilzpigmente IV. Anthrachinon-Pigmente aus Dermocybe sanguinea (Wulf. ex Fr.) Wünsche und D. semisanguinea (Fr.). Chem. Ber. 1969, 102, 4104-4118. [CrossRef]

65. Steglich, W.; Lösel, W.; Pilzpigmente, X. Anthrachinon-glucoside aus Dermocybe sanguinea (Wulf. ex Fr.) Wünsche. Chem. Ber. 1972, 105, 2928-2932. [CrossRef] [PubMed]

66. Räisänen, R. Anthraquinones from the Fungus Dermocybe sanguinea as Textile Dyes. Doctoral Dissertation, University of Helsinki, Helsinki, Finland, 2002. Available online: http://urn.fi/URN:ISBN:978-952-10-5928-5 (accessed on 14 October 2019).

67. Stensrud, Ø.; Orr, R.J.S.; Reier-Røberg, K.; Schumacher, T.; Høiland, K. Phylogenetic relationships in Cortinarius with focus on North European species. Karstenia 2014, 54, 57-71. [CrossRef]

68. Räisänen, R. Fungal colourants in applications-Focus on Cortinarius species. Color. Tehnol. 2019, 135, $22-31$. [CrossRef]

69. Beattie, K.D.; Rouf, R.; Gander, L.; May, T.W.; Ratkowsky, R.; Donner, C.D.; Gill, M.; Grice, I.D.; Tiralongo, E. Antibacterial metabolites from Australian macrofungi from the genus Cortinarius. Phytochemistry 2010, 71, 948-955. [CrossRef]

70. Fouillaud, M.; Venkatachalam, M.; Girard-Valenciennes, E.; Caro, Y.; Dufossé, L. Anthraquinones and 70Derivatives from Marine-Derived Fungi: Structural Diversity and Selected Biological Activities. Mar. Drugs 2016, 14, 64. [CrossRef] 
71. Berger, K.J.; Guss, D.A. Mycotoxins revisited: Part II. J. Emerg. Med. 2005, 28, 175-183. [CrossRef]

72. Dinis-Oliveira, R.J.; Soares, M.; Rocha-Pereira, C.; Carvalho, F. Human and experimental toxicology of orellanine. Hum. Exp. Toxicol. 2016, 35, 1016-1029. [CrossRef]

73. Shao, D.; Tang, S.; Healy, R.A.; Imerman, P.M.; Schrunk, D.E.; Rumbeiha, W.K. A novel orellanine containing mushroom Cortinarius armillatus. Toxicon 2016, 114, 65-74. [CrossRef]

74. Danel, V.; Saviuc, P.F.; Garon, D. Main features of Cortinarius spp. poisoning: A literature review. Toxicon 2001, 39, 1053-1060. [CrossRef]

75. FinBIF. Finnish Biodiversity Information Facility. Cortinarius semisanguineus and Salix phylicifolia. 2018. Available online: https://laji.fi/taxon/MX.72871 (accessed on 14 October 2019).

76. Dong, X.; Fu, J.; Yin, X.; Cao, S.; Li, X.; Lin, L.; Huyiligeqi; Ni, J. Emodin: A review of its pharmacology, toxicity and pharmacokinetics. Phytother. Res. 2016, 30, 1207-1218. [CrossRef] [PubMed]

77. Chen, C.; Gao, J.; Wang, T.-S.; Guo, C.; Yan, Y.-J.; Mao, C.-Y.; Gu, L.-W.; Yang, Y.; Li, Z.-F.; Liu, A. NMR-based metabolomic techniques identify the toxicity of emodin in HepG2 cells. Sci. Rep. 2018, 8, 9379. [CrossRef] [PubMed]

78. Von Wright, A.; Raatikainen, O.; Taipale, H.; Kärenlampi, S.; Mäki-Paakkanen, J. Directly acting geno- and cytotoxic agents from a wild mushroom Dermocybe sanguinea. Mutat. Res. Fundam. Mol. Mech. Mutagen. 1992, 269, 27-33. [CrossRef]

79. Salo, P.; Niemelä, T.; Salo, U. Suomen Sieniopas; Handbook of Fungi in Finlan; LUOMUS Finnish Museum of Natural History, Botany, WSOY: Helsinki, Finland, 2006.

80. Holzapfel, M.; Kilpert, C.; Steglich, W. Uber Leucomentine, farblose Vorstufen des Atromentins aus dem SamtfuBkrempling (Paxillus atrotomentosus). Liebigs Ann. Chem. 1989, 8, 797-801. [CrossRef]

81. Besl, H.; Bresinsky, A.; Geigenmuller, G.; Herrmann, R.; Kilpert, C.; Steglich, W. Flavomentine und Spiromentine, neue Terphenylchinon-Derivate aus Paxillus atrotomentosus und P. panuoides (Boletales). Liebigs Ann. Chem. 1989, 8, 803-810. [CrossRef]

82. Buchanan, M.S.; Hashimoto, T.; Takaoka, S.; Asakawa, Y. (+)-osmundalactone, $\gamma$-lactones and spiromentins from the fungus Paxillus atrotomentosus. Phytochemistry 1995, 40, 1251-1257. [CrossRef]

83. Heikkinen, S. Sustainable Colour from Nature? The Effect of Salix phylicifolia and Rheum cultorum as Mordants to Colour and Colour Fastness of Wool Dyed with Dermocybe semisanguinea [in Finnish]. Master's Thesis, University of Helsinki, Helsinki, Finland, 2010.

84. Loukojärvi, L.-K. Effect of Detergent on Colour Change and Colour Fastness of Natural Dyed Wool in Washing [in Finnish]. Master's Thesis, University of Helsinki, Helsinki, Finland, 2010.

85. Räisänen, R.; Björk, H.; Hynninen, P.H. Two-dimensional TLC separation and mass spectrometric identification of anthraquinones isolated from the fungus Dermocybe sanguinea. Z. Naturforsch. C J. Biosci. 2000, 55c, 195-202. [CrossRef]

86. Huheey, J.E. Inorganic Chemistry. Principles of Structure and Reactivity, 3rd ed.; Harper \& Row: New York, NY, USA, 1983.

87. Triana, J.; Eiroa, J.L.; Morales, M.; Pérez, F.J.; Brouard, I.; Marrero, M.T.; Estévez, S.; Quintana, J.; Estévez, F.; Castillo, Q.A.; et al. A chemotaxonomic study of endemic species of genus Tanacetum from the Canary Islands. Phytochemistry 2013, 92, 87-104. [CrossRef]

88. Bączek, K.B.; Kosakowska, O.; Przybył, J.L.; Pióro-Jabrucka, E.; Costa, R.; Mondello, L.; Gniewosz, M.; Synowiec, A.; Węglarz, Z. Antibacterial and antioxidant activity of essential oils and extracts from costmary (Tanacetum balsamita L.) and tansy (Tanacetum vulgare L.). Ind. Crop. Prod. 2017, 102, 154-163. [CrossRef]

89. Venditti, A.; Frezza, C.; Sciubba, F.; Serafini, M.; Bianco, A.; Cianfaglione, K.; Lupidi, G.; Quassinti, L.; Bramucci, M.; Maggi, F. Volatile components, polar constituents and biological activity of tansy daisy (Tanacetum macrophyllum (Waldst. et Kit.) Schlutz Bip.). Ind. Crop Prod. 2018, 118, 225-235. [CrossRef]

90. Coté, H.; Boucher, M.-A.; Pichette, A.; Legault, J. Anti-inflammatory, antioxidant, antibiotic and cytotoxic activities of Tanacetum vulgare L. essential oil and its constituents. Medicines 2017, 4, 1-9. [CrossRef] [PubMed]

91. Schneider, P.; Bouhired, S.; Hoffmeister, D. Characterization of the atromentin biosynthesis genes and enzymes in the homobasidiomycete Tapinella panuoides. Fungal Genet. Biol. 2008, 45, 1487-1496. [CrossRef]

92. Goyal, S.; Ramawat, K.G.; Mérillon, J.-M. Different Shades of Fungal Metabolites: An Overview. In Fungal Metabolites; Mérillon, J.-M., Ramawat, K.G., Eds.; Springer: Cham, Switzerland, 2017; pp. 1-29.

93. Mérillon, J.-M.; Ramawat, K.G. (Eds.) Fungal Metabolites; Springer: Cham, Switzerland, 2017.

94. Liu, J.-K. Natural terphenyls: Developments since 1877. Chem. Rev. 2006, 106, 2209-2223. [CrossRef] 
95. Kopponen, P.; Asikainen, M.; Törrönen, R.; Klemola, K.; Liesivuori, J.; Kärenlampi, S. In vitro cytotoxicity of textile dyes and extracts of dyed/finished fabrics. Altern. Lab. Animals 1997, 25, 539-546.

96. Benassi-Zanqueta, É.; Marques, C.F.; Valone, L.M.; Pellegrini, B.L.; Bauermeister, A.; Ferreira, I.C.P.; Lopes, N.P.; Nakamura, C.V.; Dias Filho, B.P.; Natali, M.R.; et al. Evaluation of anti-HSV-1 activity and toxicity of hydroethanolic extract of Tanacetum parthenium (L.) Sch.Bip. (Asteraceae). Phytomedicine 2019, 55, 249-254. [CrossRef]

97. Pearson, J.; Liesivuori, J.; Lindström-Seppä, P. Evaluating the toxicity of fabric extracts using the hepa-1 cytotoxicity test, the HaCaT cytotoxicity test and the spermatozoa motility inhibition test. J. Text. Inst. 2009, 100, 330-337. [CrossRef]

98. Pihlava, J.-M.; Hellström, J.; Kurtelius, T.; Mattila, P. Flavonoids, anthocyanins, phenolamides, benzoxazinoids, lignans and alkylresorcinols in rye (Secale cereale) and some rye products. J. Cereal Sci. 2018, 79, 183-192. [CrossRef]

99. Vanden Berghe, I.; Gleba, M.; Mannering, U. Towards the identification of dyestuffs in Early Iron Age Scandinavian peat bog textiles. J. Archaeol. Sci 2019, 36, 1910-1912. [CrossRef]

100. Smith, K.J. Colour-order systems, colour spaces, colour difference and colour scales. In Colour Physics for Industry, 2nd ed.; McDonald, R., Ed.; Society of Dyers and Colourists: Bradford, UK, 1997.

101. Borenfreund, E.; Puerner, J.A. A simple quantitative procedure using monolayer cultures for cytotoxicity assays (HTD/NR-90). J. Tissue Cult. Methods 1984, 9, 7-9. [CrossRef]

(C) 2020 by the authors. Licensee MDPI, Basel, Switzerland. This article is an open access article distributed under the terms and conditions of the Creative Commons Attribution (CC BY) license (http://creativecommons.org/licenses/by/4.0/). 